\title{
Aziridination of Alkenes Promoted by Iron or Ruthenium Complexes
}

\author{
Caterina Damiano, Daniela Intrieri and Emma Gallo* \\ Department of Chemistry, University of Milan, Via C. Golgi 19, 20133 Milan (Italy). E-mail \\ address: emma.gallo@unimi.it.
}

Keywords: Aziridines, Nitrene reagents, Alkenes, Homogenous catalysis, Iron, Ruthenium.

\begin{abstract}
Molecules containing an aziridine functional group are a versatile class of organic synthons due to the presence of a strained three member, which can be easily involved in ring-opening reactions and the aziridine functionality often show interesting pharmaceutical and/or biological behaviours. For these reasons, the scientific community is constantly interested in developing efficient procedures to introduce an aziridine moiety into organic skeletons and the one-pot reaction of an alkene double bond with a nitrene [NR] source is a powerful synthetic strategy.

Herein we describe the catalytic activity of iron or ruthenium complexes in promoting the reaction stated above by stressing the potential and limits of each synthetic protocol.

\section{Introduction}

Aziridines, the smallest $N$-heterocycle compounds, have attracted considerable attention in the last few decades due to their many applications in biological and synthetic chemistry [1]. The aziridine functionality is often responsible for the activity of biologically active species (such as antitumor compounds, antibiotics and enzyme inhibitors) and aziridine containing molecules [2] are also useful building blocks in the synthesis of fine chemicals and pharmaceuticals [3-6]. The striking chemical properties of aziridines are due to the energy associated to the strained threemembered ring [7], which renders them very active and versatile starting materials for the synthesis of several useful molecules such as amines, amino acids, $\beta$-lactams, polymers and $\alpha$-amido ketones $[8,9]$.

In view of their interesting chemical peculiarities and the scarcity of widespread procedures for their preparation [10], the scientific community is constantly interested in the development of new synthetic protocols which are more efficient than traditional methods such as cyclization of amino alcohols or the reaction between imines and diazo-containing compounds [9, 11, 12].
\end{abstract}


Among available synthetic strategies, the direct aziridination of alkenes promoted by transition metal complexes is a very interesting and promising approach, where the catalytic performance can be tuned up by selecting the opportune nitrene source and metal catalyst (Scheme 1) [13].

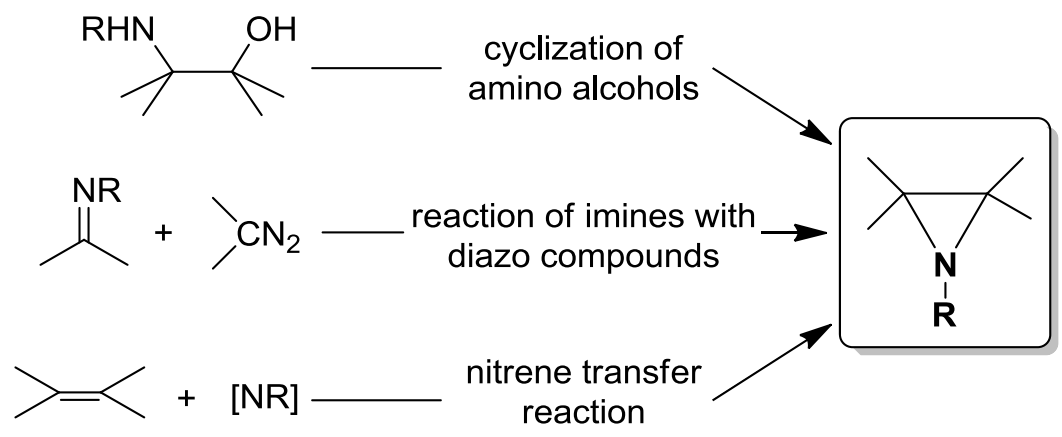

Scheme 1. General synthetic pathways affording aziridines.

Iminoiodinane compounds [14], amides in presence of hypervalent iodine reagents [15], haloamine-T salts [16] and organic azides [17-19] represent the most applied classes of nitrogen sources and the latter have recently received great attention as nitrene transfer agents due to their high atom efficiency. On the other hand, numerous transition metal catalysts [20] have demonstrated to be efficient promoters of nitrene transfer reactions and among them, complexes of group 8 metals is one of the most active classes [14, 21-23].

This review summarises the most important results obtained during about last ten years (from 2006 to March 2017) on the catalytic activity of iron or ruthenium complexes to promote the catalytic aziridination of alkenes by focusing a particular attention on innovative catalytic systems which combine good performance with good eco-tolerability. Thus, the employment of iron derivatives is of noticeable importance due to the abundance of iron metal on Earth associated to its low cost and low biological toxicity as well as attractive chemical properties. The contents of this review are categorised by the type of ligand employed to synthesise iron or ruthenium complexes and data reported in the literature up to March 2017 are herein discussed. We hope that this report will stimulate further research interest in this area and we sincerely apologise in advance if some important contributions have been unintentionally omitted.

\section{Metal Porphyrin Catalysts}

\subsection{Iron.}

Metal porphyrin complexes have been extensively employed as aziridination catalysts [24-26] and since it was established that iron porphyrins efficiently promote the reaction of alkenes with $\mathrm{PhI}=\mathrm{NR}$ compounds leading $N$-substituted aziridines [27], several papers were published up to 2006 
[28-32]. As stated above, the catalytic sustainability of iron complexes is currently pushing the scientific community to devote more attention to the study of the catalytic properties of these species. In 2010, C. M. Che's research group [33] tested the activity of different iron (II) and iron (III) porphyrins in aziridination of styrene by $\mathrm{TsN}_{3}$ ( $\mathrm{Ts}=4$-toluenesulfonyl) and best results were obtained by using [ $\left.\mathrm{Fe}^{\mathrm{III}}\left(\mathrm{F}_{20}-\mathrm{TPP}\right) \mathrm{Cl}\right](\mathbf{1})\left(\mathrm{F}_{20} \mathrm{TPP}=\right.$ dianion of meso-tetrakis-(pentafluorophenyl) porphyrin) where the iron metal is coordinated to an electron poor fluorinate porphyrin ligand. Both electron-poor and electron-rich substituted styrenes were aziridinated forming aziridines 2-11 (Scheme 2) with excellent yields up to $95 \%$ and the catalytic procedure was also effective to convert aliphatic alkenes into corresponding aziridines 12-17 (Scheme 2) in good yields (up to $85 \%)$.
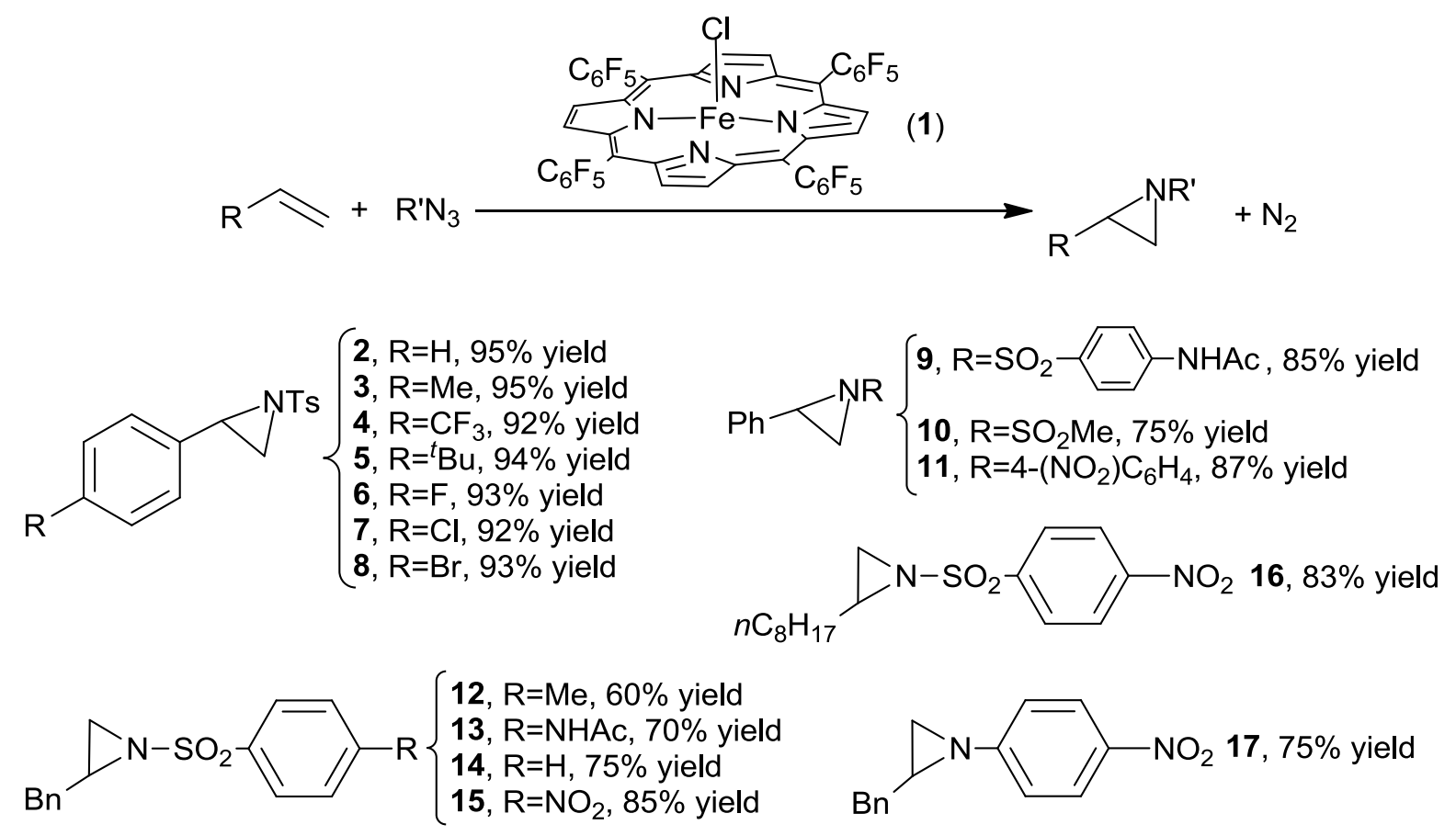

Scheme 2. Synthesis of aziridines catalysed by $\left[\mathrm{Fe}^{\mathrm{III}}\left(\mathrm{F}_{20}-\mathrm{TPP}\right) \mathrm{Cl}\right](\mathbf{1})$.

It should be noted that the aziridination of some less reactive substrates was run under microwave irradiations with a consequent enhance of the catalytic efficiency both in terms of the reaction time and productivity.

Considering that metal porphyrins are involved in several processes that sustain living systems and constitute the active site of many enzymes, a great effort has been devoted to the engineering of natural enzymes in order to create new biocatalysts active in promoting non-natural reactions. In this contest, F. A. Arnold and co-authors reported in 2015 [34] the catalytic activity of engineered enzymes obtained by replacing some specific residues of cytochrome $\mathrm{P} 450_{\mathrm{BM} 3}$. Among all the mutated enzymes, the biocatalyst P-I263F (18) ( $\left.\mathrm{P}=\mathrm{P} 411_{\mathrm{BM} 3}-\mathrm{CIS}-\mathrm{T} 438 \mathrm{~S}\right)$ was active in catalysing 
the reaction of 4-methyl styrene with $\mathrm{TsN}_{3}$ to form aziridine 3 with $40 \%$ yield and with a $55 \%$ ee of $(S)$-enantiomer.

Two subsequent mutations of P-I263F were then responsible for the formation of P-I263FA328V-L437V (19), which showed a better catalytic efficiency than the parent P-I263F enzyme and aziridine 3 was achieved with a larger yield (55\%) and outstanding $(S)$-selectivity of $99 \%$ ee. The scope of the reaction was investigated in the presence of biocatalyst 19 and both electron rich and electron poor styrenes were converted into corresponding aziridines by using $\mathrm{TsN}_{3}$ as the aminating agent (Scheme 3). Data reported in Scheme 3 shows that even if the aziridination of encumbered alkenes occurred with very high enantioselectivities, desired aziridines $\mathbf{2 0 - 2 3}$ were formed in very low reaction yields.
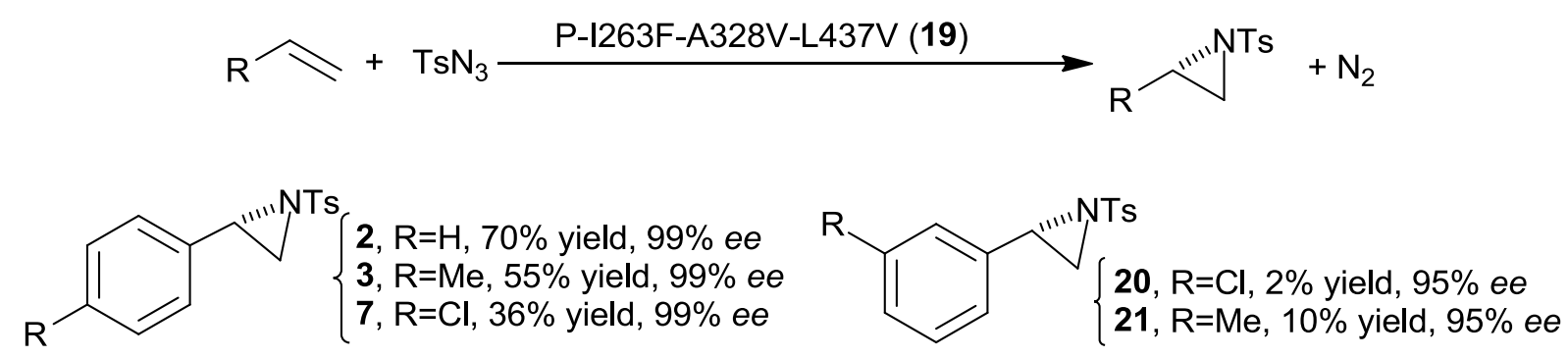<smiles>Cc1ccc(C2C[NH2+]2)c(C)c1</smiles>

22, $15 \%$ yield, $81 \%$ ee

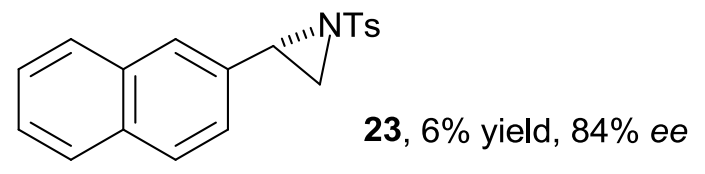

Scheme 3. Synthesis of aziridines catalysed by P-I263F-A328V-L437V (19) enzyme.

To the best of our knowledge the mechanism of iron porphyrin-catalysed aziridination has not been explained in detail up to now. The formation of a (porphyrin) ${ }^{+\bullet} \mathrm{Fe}=\mathrm{NR}(\mathrm{L})$ imido intermediate, active in transferring the nitrene functionality 'NR' to a double bond of an alkene substrate, was suggested in analogy to mechanistic proposals regarding oxidation reactions mediated by highvalent iron-oxo porphyrins. A DFT study of the catalytic activity of (porphyrin) ${ }^{+\bullet} \mathrm{Fe}=\mathrm{NR}(\mathrm{L})$ species in the alkene aziridination disclosed that the nitrene transfer reaction could occur by a stepwise process in which the $\pi$-bond activation of the alkene is followed by a ring closure step forming aziridine (Scheme 4) [35]. 


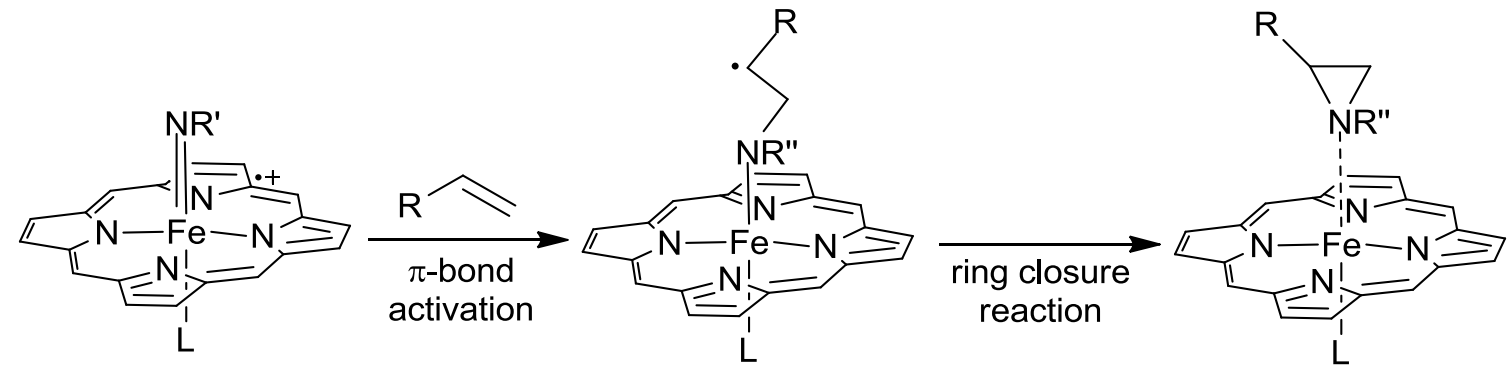

Scheme 4. Proposed mechanistic pathway for the nitrene transfer reaction.

Considering that dipyrromethene ligands can be considered as a half porphyrin molecule, dipyrrinato iron catalysts are discussed in this section dedicated to porphyrin ligands. T. A. Betley and co-authors synthesised iron (II) complexes 24 [36] and 25 [37] to use them as catalysts for the aziridination of several alkenes which led to compounds 26-33 reported in Scheme 5. Both alkyl and aryl azides were converted into desired aziridines with yields up to $86 \%$.
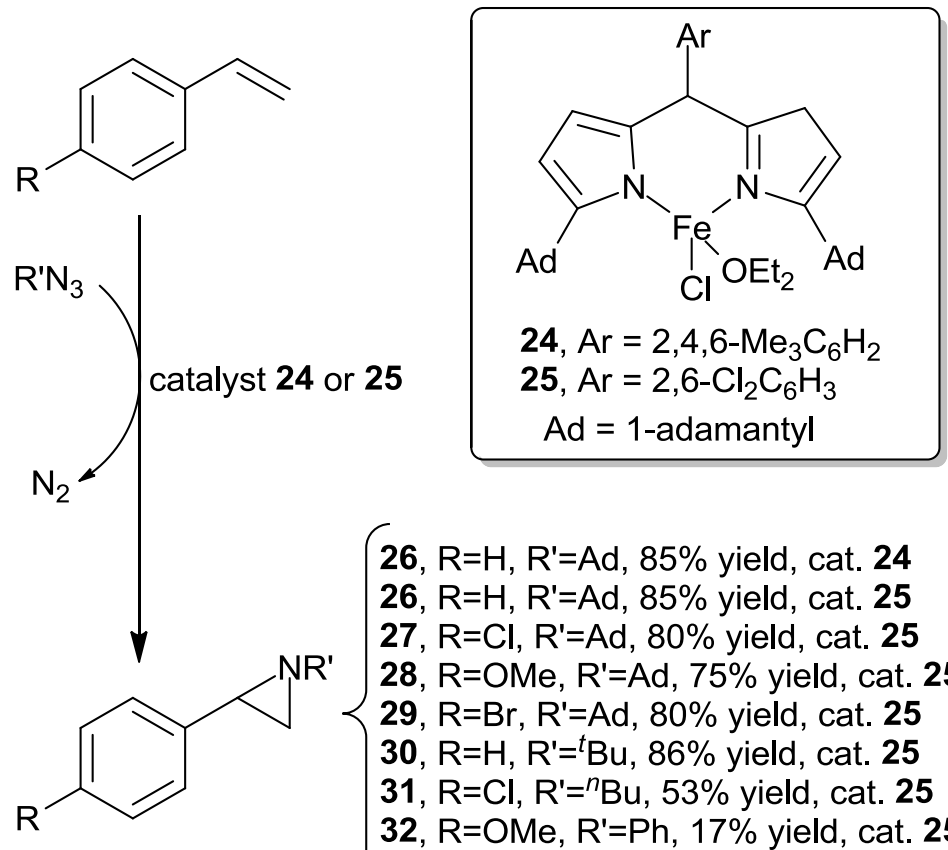

26, $\mathrm{R}=\mathrm{H}, \mathrm{R}^{\prime}=\mathrm{Ad}, 85 \%$ yield, cat. 24

26, $\mathrm{R}=\mathrm{H}, \mathrm{R}^{\prime}=\mathrm{Ad}, \mathbf{8 5} \%$ yield, cat. 25

27, $\mathrm{R}=\mathrm{Cl}, \mathrm{R}^{\prime}=\mathrm{Ad}, 80 \%$ yield, cat. 25

28, $R=O M e, R^{\prime}=A d, 75 \%$ yield, cat. 25

29, $\mathrm{R}=\mathrm{Br}, \mathrm{R}^{\prime}=\mathrm{Ad}, \mathbf{8 0} \%$ yield, cat. 25

$30, \mathrm{R}=\mathrm{H}, \mathrm{R}^{\prime}={ }^{t} \mathrm{Bu}, 86 \%$ yield, cat. 25

31, $\mathrm{R}=\mathrm{Cl}, \mathrm{R}^{\prime}={ }^{n} \mathrm{Bu}, 53 \%$ yield, cat. 25

32, $\mathrm{R}=\mathrm{OMe}, \mathrm{R}^{\prime}=\mathrm{Ph}, 17 \%$ yield, cat. 25

33, $\mathrm{R}=\mathrm{Br}, \mathrm{R}^{\prime}=4-{ }^{\mathrm{t}} \mathrm{BuC}_{6} \mathrm{H}_{4}, 64 \%$ yield, cat. 25

Scheme 5. Aziridination reactions catalysed by dipyrrinato iron (II) complexes $\mathbf{2 4}$ and 25.

The authors proposed that the catalytic reaction occurred via a radical mechanism in which an iron imido radical intermediate was the catalytically active species (Scheme 6). This proposal was supported by the isolation and complete characterisation, including X-ray structural determination, of complex 34 where a high-spin Fe ${ }^{\mathrm{III}}$ metal centre was coupled to an imido radical nitrogen atom. 


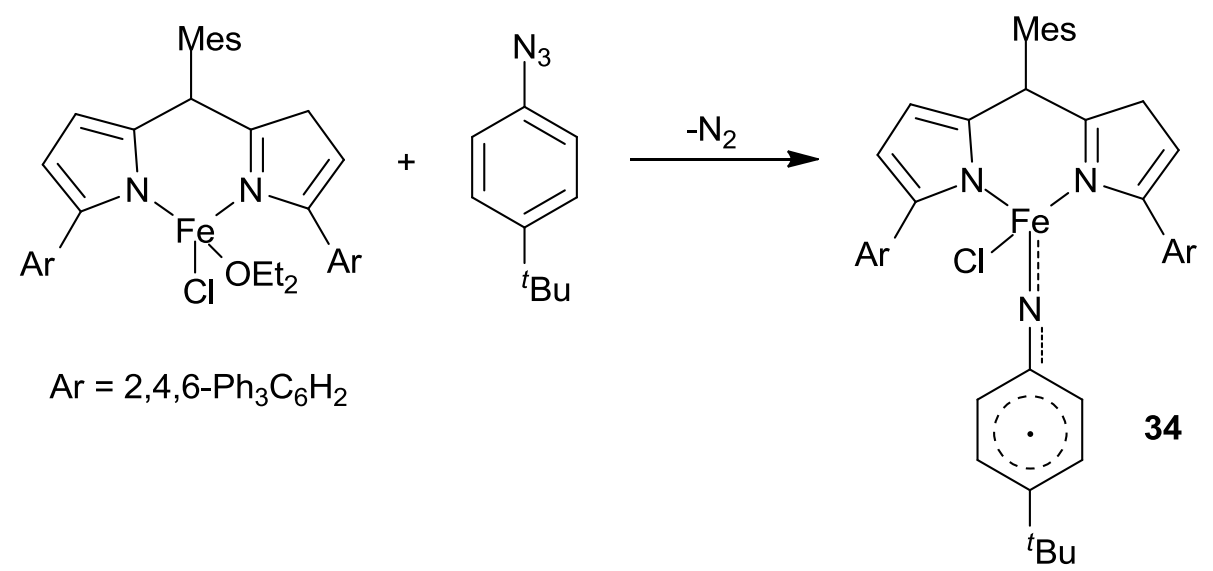

Scheme 6. Synthesis of supposed nitrene-transfer active intermediate $(\mathrm{L}) \mathrm{Fe}^{\mathrm{III}} \mathrm{Cl}(\cdot \mathrm{NR})$ ( $\mathrm{L}=$ dipyrrinato ligand) 34 .

An iron imido radical species with a molecular structure similar to 34 was reacted with a dimeric ferrous species to synthesise complex $\mathbf{3 5}$, which was also active in transferring the nitrene unit to styrene to form the corresponding aziridine (Scheme 7) [38].

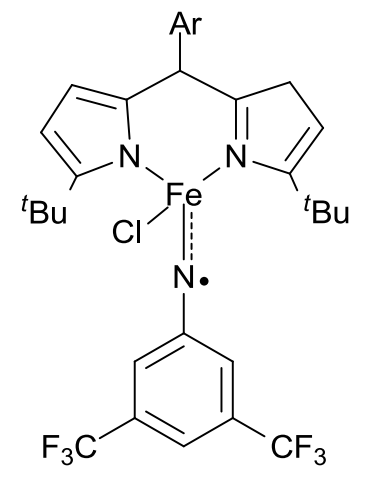

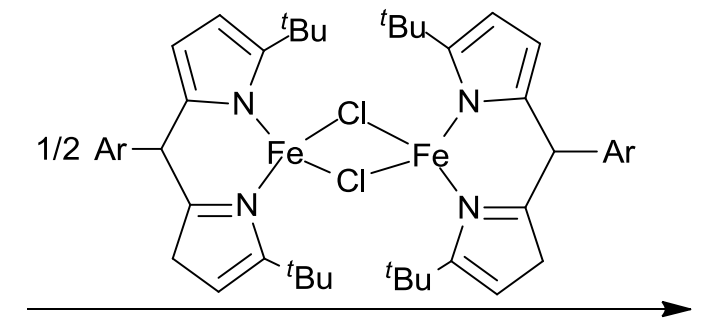

$\mathrm{Ar}=2,6-\mathrm{Cl}_{2} \mathrm{C}_{6} \mathrm{H}_{3}$

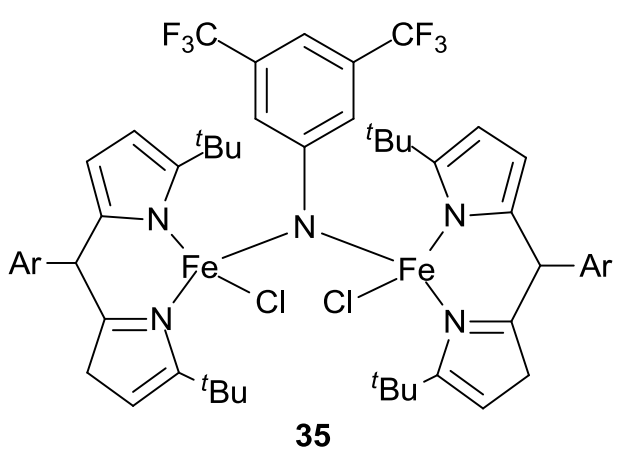

Scheme 7. Synthesis of complex 35.

\subsection{Ruthenium.}

Ruthenium porphyrin complexes are very active promoters of aziridination reactions by using either iminoiodinane compounds (ArI=NR) [39-43] or organic azides $\left(\mathrm{RN}_{3}\right)$ however, since 2006 the latter aminating agents have mainly been used as nitrene sources due to their more sustainable peculiarities. In particular, $\mathrm{Ru}$ (porphyrin) $\mathrm{CO}$ complexes 36-47 (Chart 1) were very active for the synthesis of $\mathrm{N}$-aryl aziridines obtained from the reaction of alkenes with aryl azides [44]. 


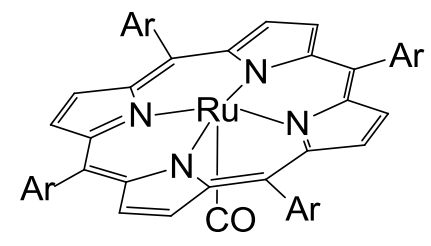

36, $\mathrm{Ar}=\mathrm{C}_{6} \mathrm{H}_{5}$ 37, $\mathrm{Ar}=4-\mathrm{CF}_{3} \mathrm{C}_{6} \mathrm{H}_{4}$ 38, $\mathrm{Ar}=4-\mathrm{FC}_{6} \mathrm{H}_{4}$ 41, $\mathrm{Ar}=4-(\mathrm{OMe}) \mathrm{C}_{6} \mathrm{H}_{4}$ 39, $\mathrm{Ar}=4-\mathrm{ClC}_{6} \mathrm{H}_{4}$ 40, $\mathrm{Ar}=4-{ }^{-} \mathrm{BuC}_{6} \mathrm{H}_{4}$

42, $\mathrm{Ar}=4-(\mathrm{MeOCO}) \mathrm{C}_{6} \mathrm{H}_{4}$

43, $\mathrm{Ar}=3,5-\left(\mathrm{CF}_{3}\right)_{2} \mathrm{C}_{6} \mathrm{H}_{3}$

44, $\mathrm{Ar}=2,4,6-(\mathrm{Me})_{3} \mathrm{C}_{6} \mathrm{H}_{2}$

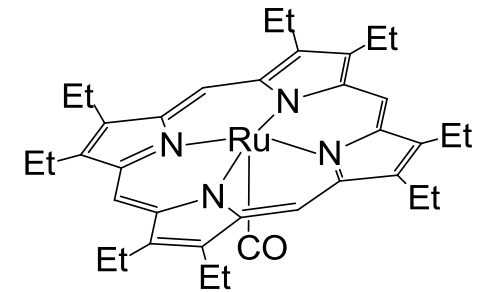

45

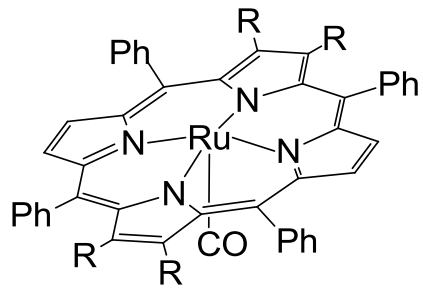

46, $\mathrm{R}=\mathrm{Br}$

47, $\mathrm{R}=\mathrm{Ph}$

Chart 1. Structures of ruthenium catalysts 36-47

Catalyst $\mathrm{Ru}(\mathrm{TPP}) \mathrm{CO}$ (36) (TPP = dianion of meso-tetrakis-(phenyl) porphyrin) was employed to study the reaction scope by reacting several aryl azides with differently substituted alkenes to form 37 differently substituted aziridines (Scheme 8) and best results were achieved by using terminal alkenes and electron poor azides.
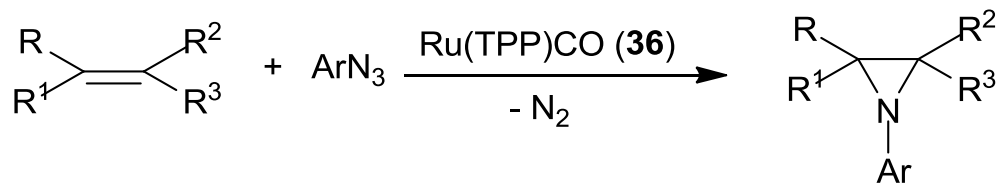

37 compounds

Scheme 8. Ru(TPP)CO (36)-catalysed synthesis of $N$-aryl aziridines.

To enlarge the scope of the synthetic procedure, ruthenium porphyrin complexes were also used to catalyse the reaction of conjugated dienes with aryl azides, which afforded $\mathrm{N}$-aryl-2vinylaziridines with very good chemoselectivities [45]. Considering that this class of very reactive compounds can easily be involved in ring-opening or ring-expansion reactions, the conversion of $\mathrm{N}$-aryl-2-vinylaziridines into heterocycle molecules A-D (Scheme 9) by using silica as an acidic promoter [46] was also investigated.

As reported in Scheme 9, when at least one hydrogen atom is present on $\mathrm{C}_{5}$ of diene, a [3,3]-Claisen rearrangement can occur forming benzoazepines (A) through the cleavage of the aziridine $\mathrm{C}_{3}-\mathrm{N}_{1}$ bond and a consecutive proton shift from the aryl moiety to the nitrogen atom (path a). Conversely, when $N$-aryl-2-vinylaziridine presented a sterically encumbered double bond, the formation of benzoazepines was hampered and 2,3-dihydropyrroles (B) were formed instead (path $b$ ). Finally, when high reaction temperatures were applied, the aryl group of $N$-aryl-2-vinylaziridine was not involved in the rearrangement process and 2,5-dihydropyrroles $(\mathbf{C})$ were the final reaction 
products (path c). In order to propose a mechanism of the heterocycles formation, theoretical calculations, using density functional theory methods, were also carried out.

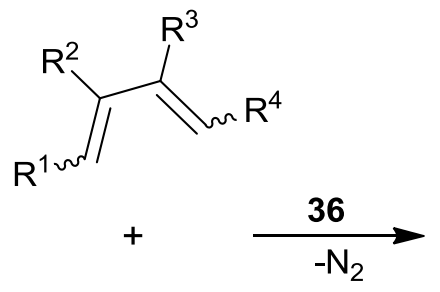

$\overbrace{(1)}^{N_{3}}$

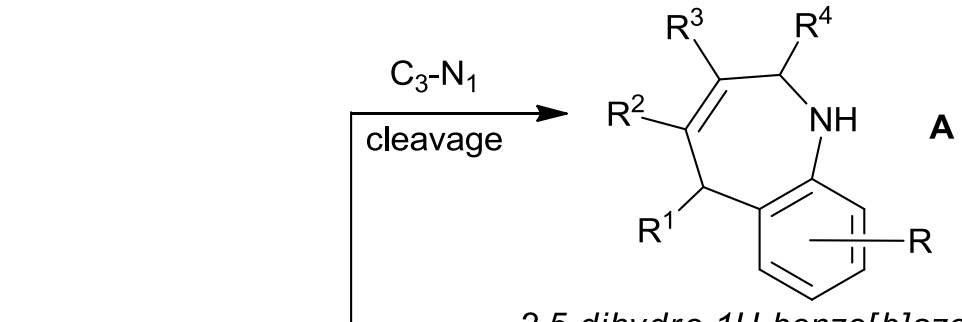

2,5-dihydro-1H-benzo[b]azepines

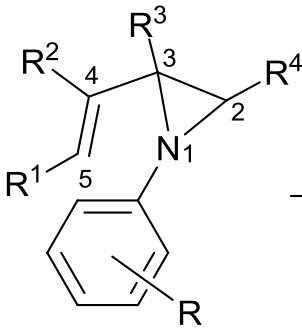

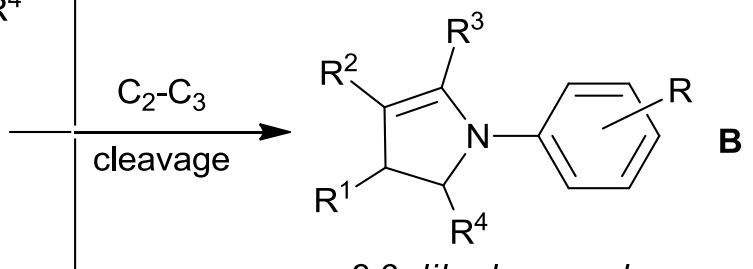

2,3-dihydropyrrole

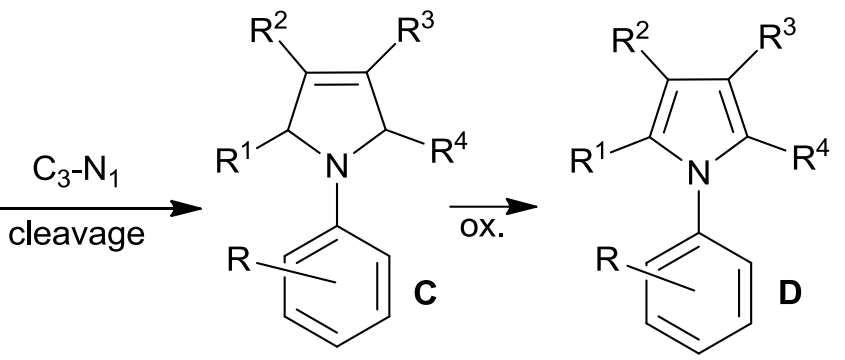

2,5-dihydropyrrole

Scheme 9. Synthesis and rearrangement of $N$-aryl-2-vinylaziridines by using $\mathrm{Ru}(\mathrm{TPP}) \mathrm{CO}(\mathbf{3 6})$ as the aziridination catalyst.

A DFT investigation, coupled with a kinetic study, was also performed to shed some light on the aziridination process mediated by ruthenium porphyrin complexes. E. Gallo, G. Manca and co-authors reported in 2015 [47] a detailed investigation, based on previously published work [48], which suggested the mechanism reported in Scheme 10 for the $\mathrm{Ru}$ (porphyrin)CO-promoted alkene aziridination.

Theoretical data indicated that, even if the initial azide coordination was an endergonic step, the formation of mono-imido (porphyrin) $\mathrm{Ru}(\mathrm{NAr}) \mathrm{CO}$ complex $\mathbf{C}$ was energetically favoured. The latter intermediate was catalytically active in interacting with the alkene to yield a diradical compound $\mathbf{D}$. After which, the electron coupling process was responsible for the aziridine formation and the consequent dismissal of the aziridine molecule from complex $\mathbf{E}$ restored catalyst $\mathbf{A}$ to permit the catalytic cycle to start again. This mechanistic hypothesis was supported by the isolation of the $\mathrm{Ru}($ porphyrin) $\mathrm{CO}$ complex at the end of the aziridination reaction. 


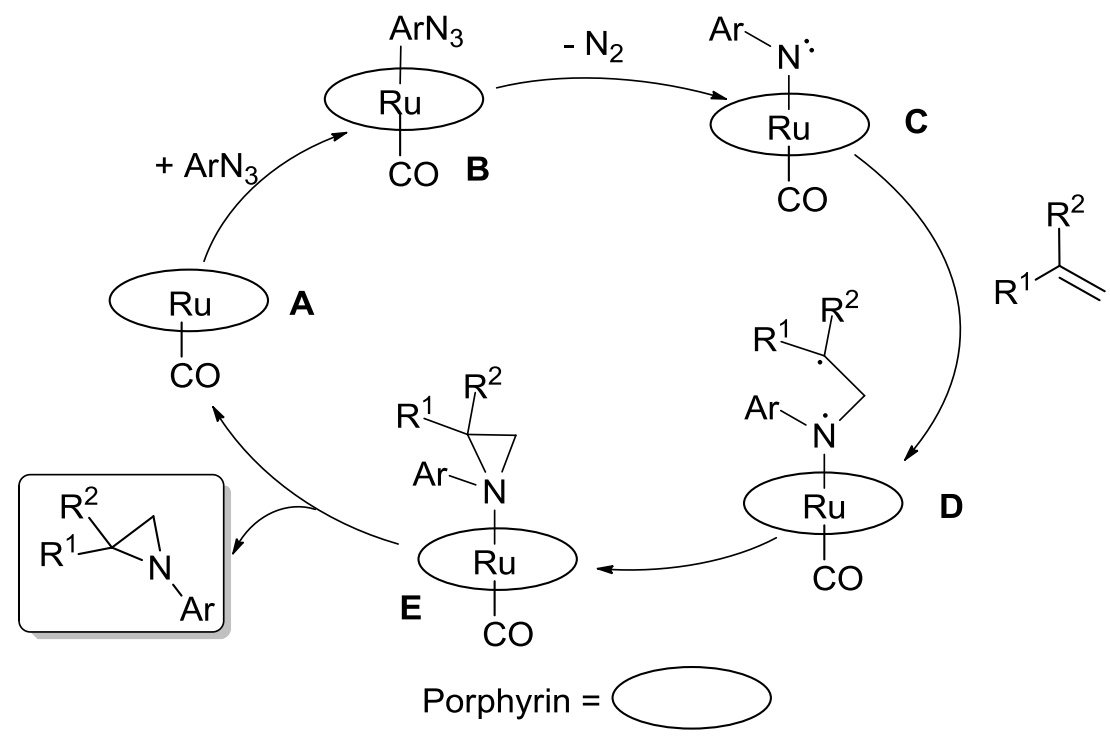

Scheme 10. Proposed mechanism for the Ru(porphyrin)CO-catalysed aziridination of alkenes by $\mathrm{ArN}_{3}$.

Considering that one of the main drawbacks of classic homogeneous catalysis is the catalyst recycling step, the use of catalytic membrane reactors (CMR), which combine the catalytic reaction with a physical in situ separation of one or more chemicals in a single apparatus, is an interesting upgrade of the catalytic procedure sustainability [49]. E. Gallo and co-authors reported the synthesis of a catalytic membrane which was obtained by embedding $\left.\mathrm{Ru}^{\mathrm{II}}\left(4-\mathrm{CF}_{3} \mathrm{TPP}\right)(\mathrm{CO})\right]$ (37) (4- $\mathrm{CF}_{3} \mathrm{TPP}$ = dianion of meso-tetrakis-(4-trifluoromethylphenyl) porphyrin) (Chart 1) into a perfluorinated polymer Hyflon AD60X (HF) [50, 51]. The high affinity of the $\mathrm{CF}_{3}$ porphyrinic groups for the polymeric membrane assured a good entrapping of the catalyst, which in turn limited the catalyst leaching during the alkene aziridination. Heterogeneous catalyst HF-37 was efficient for the synthesis of different $N$-aryl aziridines 48-52 which were obtained with selectivities larger than 98\% (Scheme 11) [52]. In several cases the membrane was reused three times with a final low catalyst leaching and no decrease in selectivities.

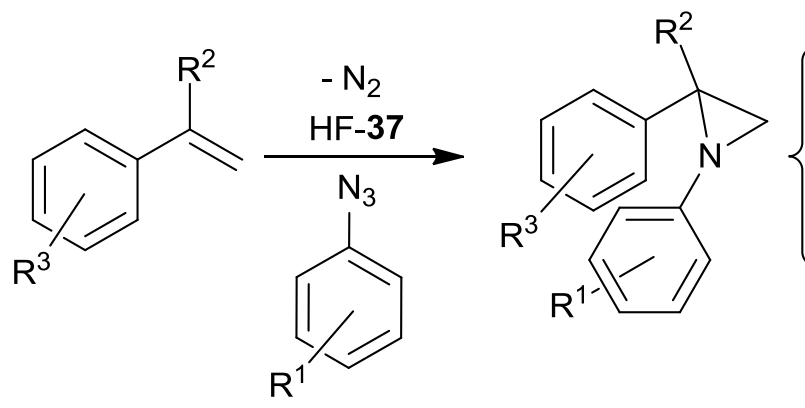

48, $\mathrm{R}^{1}=4-\mathrm{NO}_{2}, \mathrm{R}^{2}=\mathrm{Me}, \mathrm{R}^{3}=\mathrm{H}, 85 \%$ conv.; $99 \%$ sel.

49, $\mathrm{R}^{1}=4-\mathrm{NO}_{2}, \mathrm{R}^{2}=\mathrm{Ph}, \mathrm{R}^{3}=\mathrm{H}, 99 \%$ conv.; $99 \%$ sel.

50, $\mathrm{R}^{1}=4-\mathrm{NO}_{2}, \mathrm{R}^{2}=\mathrm{H}, \mathrm{R}^{3}=4-\mathrm{Cl}, 99 \%$ conv.; $99 \%$ sel.

51, $\mathrm{R}^{1}=3,5-\left(\mathrm{CF}_{3}\right)_{2}, \mathrm{R}^{2}=\mathrm{Me}, \mathrm{R}^{3}=\mathrm{H}, 98 \%$ conv.; $99 \%$ sel.

52, $\mathrm{R}^{1}=\mathrm{CN}, \mathrm{R}^{2}=\mathrm{Me}, \mathrm{R}^{3}=\mathrm{H}, 99 \%$ conv.; $99 \%$ sel.

Scheme 11. Synthesis of $N$-aryl aziridines 48-52 catalysed by HF-37. 
Another polymer-supported ruthenium porphyrin complex was obtained by reacting $\left.\mathrm{Ru}^{\mathrm{II}}\left(\mathrm{F}_{20} \mathrm{TPP}\right)(\mathrm{CO})\right]$ (53) complex with a solution of sodium PEG salt (PEG = poly(ethylene glycol)), the so obtained PEG-53 catalyst was employed to synthesise aziridines $\mathbf{2 , 5 4}$ and 55, as reported in Scheme 12 [53].

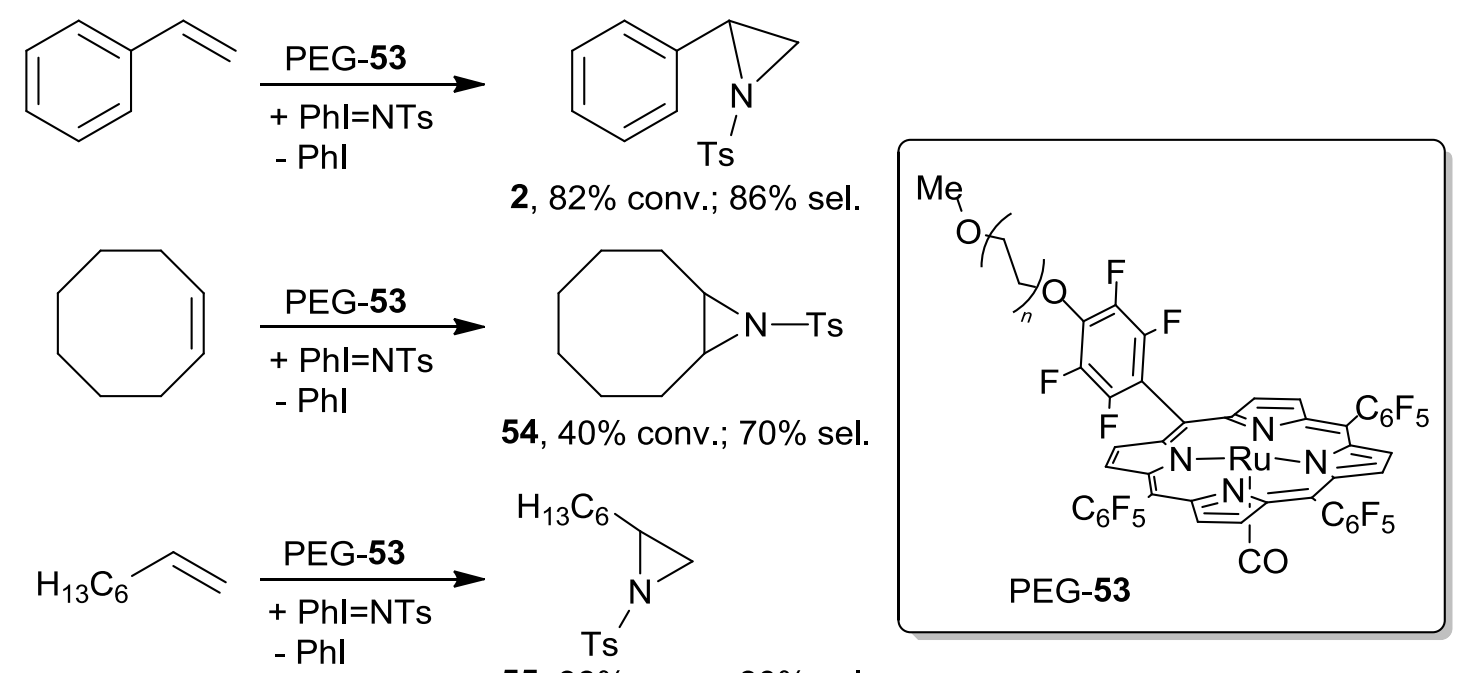

55, $38 \%$ conv.; $80 \%$ sel.

Scheme 12. Synthesis of aziridines 2, 54 and $\mathbf{5 5}$ catalysed by PEG-53.

More recently, the ruthenium porphyrin-catalysed synthesis of aziridines was performed in a PTFE mesoreactor under continuous flow conditions which enhanced the process sustainability by reducing the reaction volumes and shortening reaction times. The aziridine synthesis was performed by a two-step process where the aniline was first converted into the corresponding aryl azide, by using a modification of a reported method [54], and then the Ru(TPP)CO (36)-catalysed reaction of the azide with the alkene produced the desired aziridine molecule [55, 56]. Yields and selectivities of the second step of the flow process were comparable to those achieved by employing the standard batch procedure [44] and the reaction was performed in alkene as the reaction solvent which was easily recycled in the continuous flow process (Scheme 13).

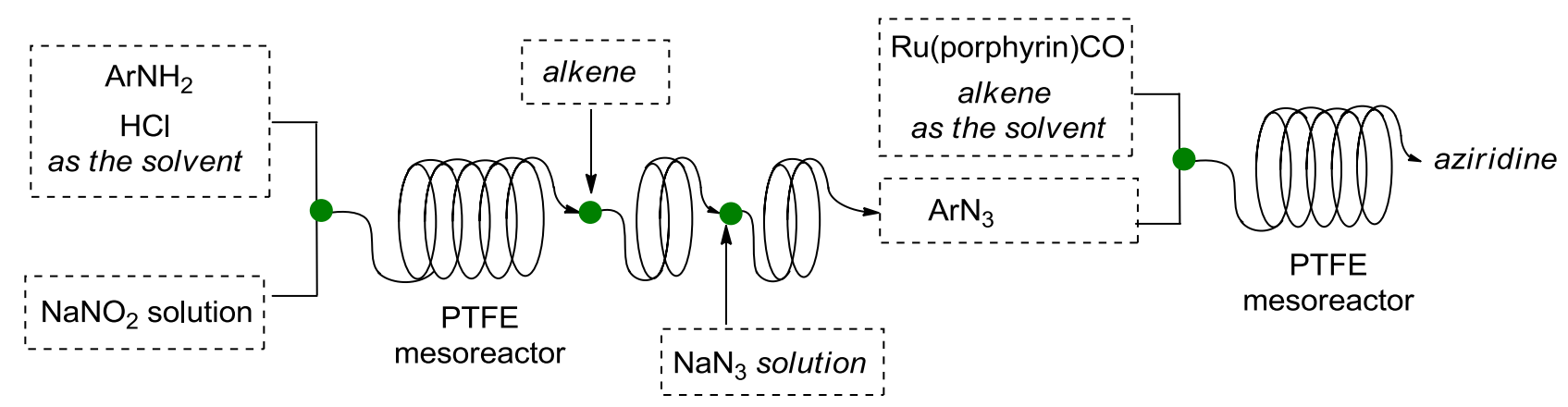

Scheme 13. Synthesis of $N$-aryl aziridines performed in a PTFE mesoreactor by using a flowcontinuous procedure. 
By using the two-step technology illustrated in Scheme 13, aziridines 48, 56-59 were obtained in $\alpha$-methylstyrene as the reaction solvent [56]. Whereas, if the first step was bypassed by treating a preformed azide with an alkene solution of $\operatorname{Ru}(\mathrm{TPP}) \mathrm{CO}(\mathbf{3 6})$, the above mentioned aziridines $\mathbf{4 8}$, 57-59, as well as $N$-aryl aziridines 51, 52, 60-64 were obtained (Chart 2).

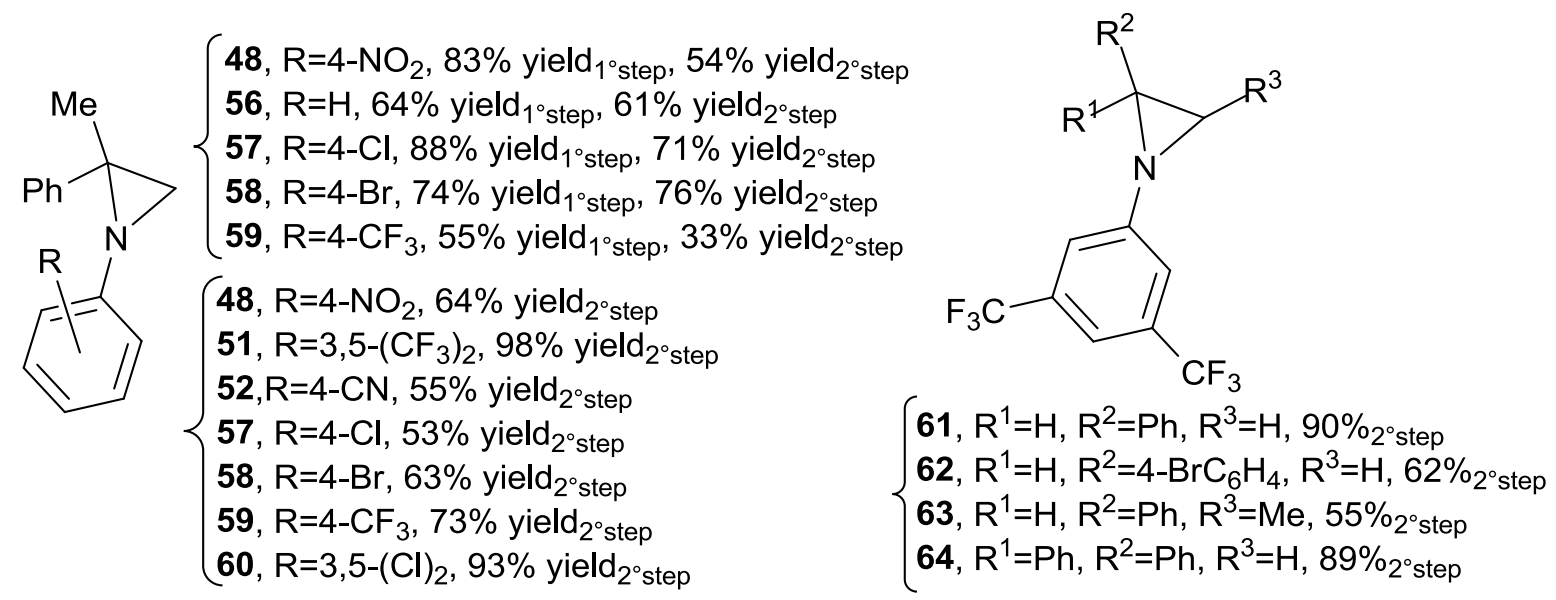

Chart 2. $N$-aryl aziridines synthesised by using a flow continuous technology.

As reported up to now, ruthenium porphyrin catalysts often display a pentacoordinated metal centre bearing a $\mathrm{CO}$ axial ligand. Then, in order to investigate the influence of axial ligands on the catalytic efficiency, C. M. Che and co-authors reported the synthesis and activity of ruthenium complexes 65 and 66, which showed BIMe (1,3-dimethyl-2,3-dihydro-1H-benzo[d]imidazole) and IMe (1,3-dimethyl-2,3-dihydro-1 $H$-imidazole), respectively as $N$-heterocyclic carbene (NHC) ligands coordinated to the ruthenium (II) centre (Figure 1).
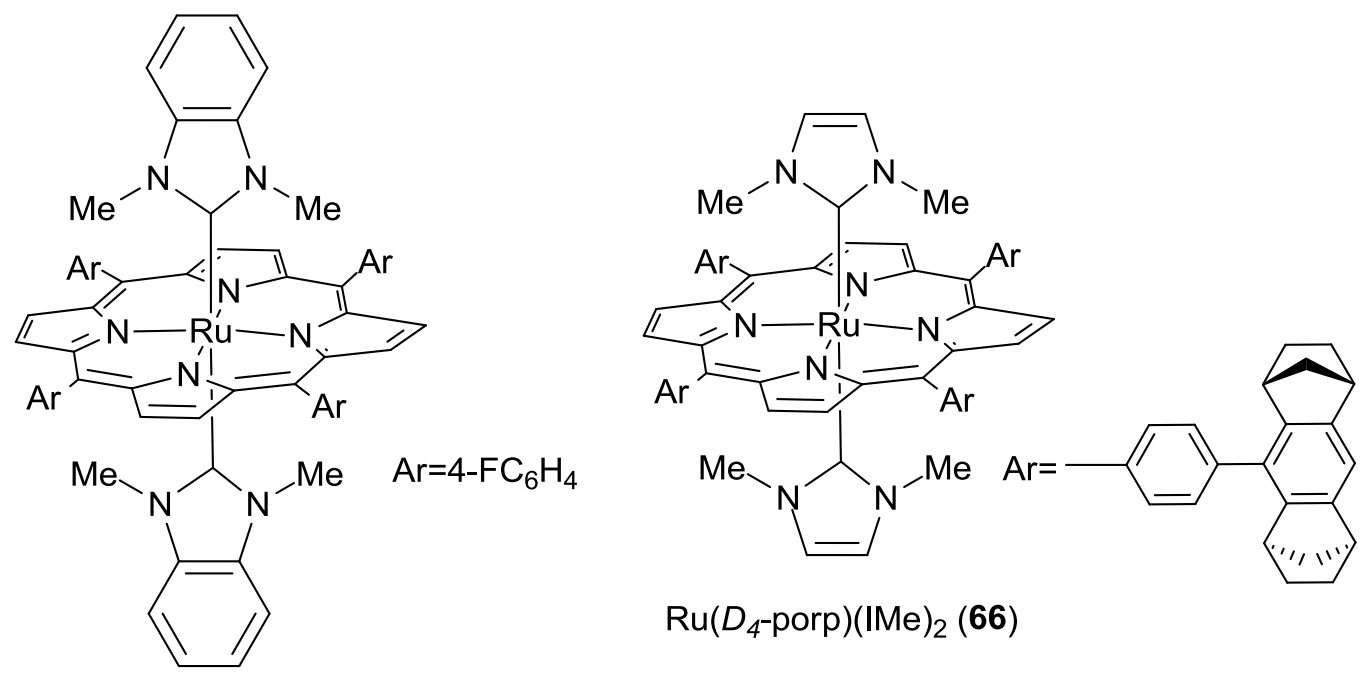

$\mathrm{Ru}\left(D_{4}\right.$-porp $)(\mathrm{IMe})_{2}(66)$

$\mathrm{Ru}(4-\mathrm{FTPP})(\mathrm{BIMe})_{2}(65)$

Figure 1. Structures of bis(NHC)ruthenium (II) porphyrin complexes 65 and 66. 
Complex 65 catalysed the synthesis of aziridines 67-74 reported in Scheme 14 from the reaction of various alkenes with pentafluorophenyl azide $\mathrm{C}_{6} \mathrm{~F}_{5} \mathrm{~N}_{3}$ [57]. The high reactivity of catalyst 65 carried out aziridination at room temperature in contrast with higher temperatures usually required to activate $\mathrm{Ru}$ (porphyrin) $\mathrm{CO}$ catalysts. This strongly supported the hypothesis that axial ligands have an active role in determining catalytic performances. The asymmetric version of this reaction was run at $-20{ }^{\circ} \mathrm{C}$ by using complex 66 as the catalytic species and chiral aziridines 67 and $\mathbf{7 4}$ were obtained in good yields and chiral purity up to $98 \%$ ee.

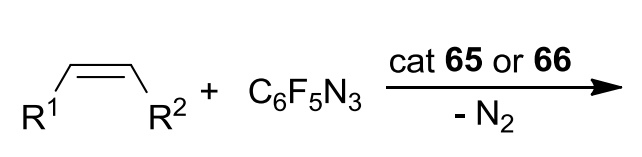<smiles>[R]c1ccc(C2CN2C(F)(F)F)cc1</smiles>

67, $\mathrm{R}=\mathrm{H}, 98 \%$ yield,cat 65

68, $\mathrm{R}=\mathrm{Me}, 99 \%$ yield, cat 65

69, $\mathrm{R}=\mathrm{F}, 95 \%$ yield, cat 65

$70, \mathrm{R}=\mathrm{Cl}, 92 \%$ yield, cat 65

$71, \mathrm{R}=\mathrm{Br}, 92 \%$ yield, cat 65

72, $\mathrm{R}=\mathrm{OMe}, 93 \%$ yield, cat 65<smiles>FC(F)(F)N1CC1P(c1ccccc1)c1ccccc1</smiles>

$67,95 \%$ yield, $80 \%$ ee, cat 66<smiles></smiles><smiles>[R]C1C([R])N1C(F)(F)F</smiles><smiles>FC(F)(F)N1C([PbH2])[C@@H]1c1ccccc1</smiles>

$73,92 \%$ yield, cat 65<smiles>FC(F)(F)N1CC1CCc1ccccc1</smiles>

$74,96 \%$ yield, cat 65

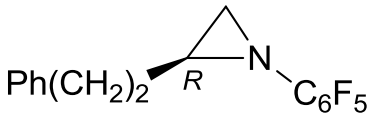

$74,85 \%$ yield, $98 \%$ ee, cat 66

Scheme 14. Synthesis of aziridines 67-74 catalysed by complexes 65 and 66.

Even if the most commonly used ruthenium porphyrin complexes display the central atom in the oxidation state of II, ruthenium IV and ruthenium VI complexes were also active in promoting the alkene aziridination. E. Gallo and co-authors [58] reported on the catalytic competence of $\left[\mathrm{Ru}^{\mathrm{IV}}(\mathrm{TPP})(\mathrm{OMe})\right]_{2} \mathrm{O}(\mathbf{7 5})$ (Figure 2) which was synthesised as reported in literature [59] whereby aziridine $\mathbf{5 1}$ was obtained in $99 \%$ yield in the presence of $1 \%$ mol of the catalyst loading.

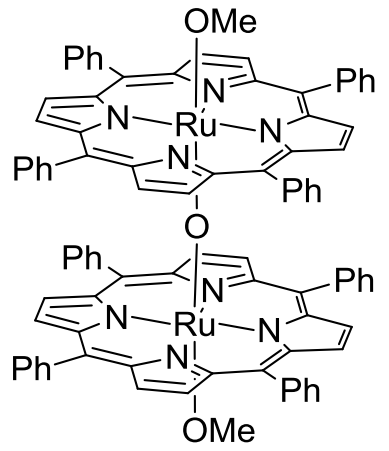

Figure 2. Structure of $\left[\mathrm{Ru}^{\mathrm{IV}}(\mathrm{TPP})\left(\mathrm{OCH}_{3}\right)\right]_{2} \mathrm{O}(\mathbf{7 5})$ 
In the case of the catalytic efficiency of ruthenium (VI) porphyrins, C. M. Che and co-authors reported the synthesis and catalytic activity of bis-imido $\mathrm{Ru}^{\mathrm{VI}}$ (porphyrin)(NY) $)_{2}$ derivatives, which were synthesised by using two different methods. The first synthetic procedure comprised of the reaction between $\mathrm{Ru}^{\mathrm{II}}$ (porphyrin)(CO) complexes and azides $\mathrm{YN}_{3}$, while the second involved the oxidation of $\mathrm{Ru}^{\mathrm{IV}}$ (porphyrin)(NHY) $)_{2}$ complexes $(\mathbf{A})$ by $\mathrm{PhI}(\mathrm{OAc})_{2}$ to form bis-imido $\mathrm{Ru}^{\mathrm{VI}}$ (porphyrin)(NY) $)_{2}$ species $(\mathbf{B})[60] . \mathrm{Ru}^{\mathrm{IV}}$ (porphyrin)(NHY) 2 amido complexes (A), obtained by reacting $\mathrm{Ru}^{\mathrm{VI}}$ (porphyrin) $\mathrm{O}_{2}$ with several $\mathrm{YNH}_{2}$, were fully characterised and in some cases their molecular structures were also solved by X-ray spectroscopy [61] (Scheme 15).

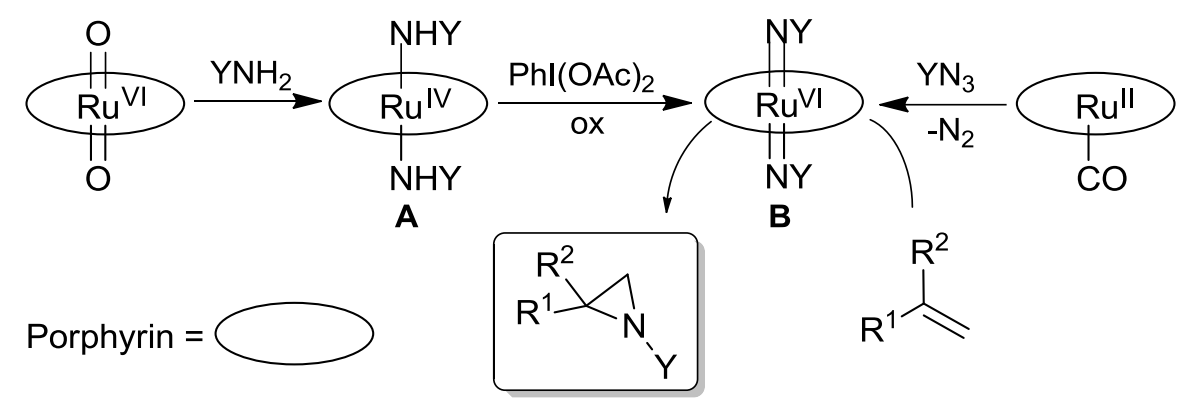

Scheme 15. Synthesis of $\mathrm{Ru}^{\mathrm{IV}}$ (porphyrin)(NHY) 2 (A) and $\mathrm{Ru}^{\mathrm{VI}}$ (porphyrin)(NY) $)_{2}(\mathbf{B})$ species.

$\mathrm{Ru}^{\mathrm{VI}}$ (porphyrin)(NY) 2 complexes were easily involved in degradation processes, which were limited by tuning electronic and steric properties of arylimide 'NY' ligands. It was observed that electron poor and sterically encumbered arylimide ligands enhanced the chemical stability of corresponding ruthenium bis-imido complexes, which were active in transferring the nitrene functionality to $\mathrm{R}^{1} \mathrm{R}^{2} \mathrm{C}=\mathrm{CH}_{2}$ alkenes yielding corresponding aziridines. In addition, the $\mathrm{Ru}^{\mathrm{VI}}$ (porphyrin)(NY) $)_{2}$-catalysed aziridination occurred with yields comparable to those observed when $\mathrm{Ru}^{\mathrm{II}}$ (porphyrin)CO was used to promote the reaction between alkenes and aryl azides.

\section{Metal Porphyrinoid Catalysts}

The catalytic activity of several metal phthalocyanines in styrene aziridination by $\mathrm{PhI}=\mathrm{NTs}$ forming 2 (Scheme 2) was reported by X.-G. Zhou and co-authors [62] who investigated the effect of the metal centre and ligand's substituent nature on the catalytic performance. Iron complexes 7679 (Figure 3) displayed better catalytic efficiencies than other metal phthalocyanines such as $\mathrm{Mn}$, $\mathrm{Ni}, \mathrm{Cu}$ and Co derivatives. 


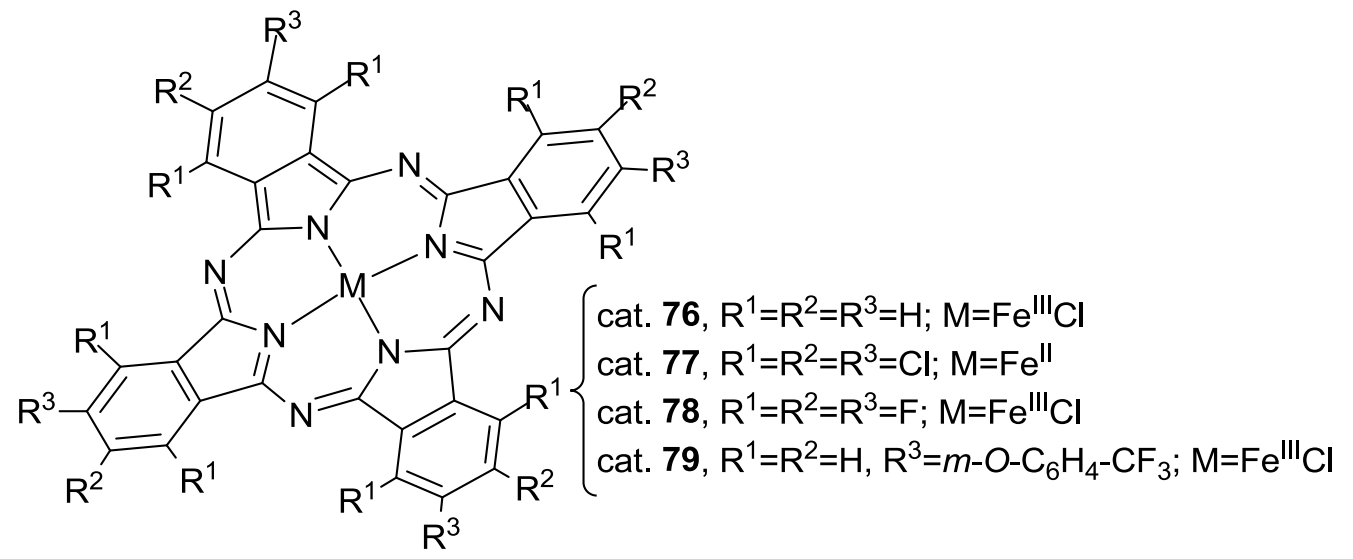

Figure 3. Structures of iron phthalocyanines 76-79

Among all tested iron catalysts, 79 mediated the synthesis of aziridine $\mathbf{2}$ with the best yield of $88 \%$ and the good activity of this complex was attributed to the presence $\mathrm{CF}_{3}$-phenoxy groups on the porphyrin ligand, which increased the complex solubility and in turn its catalytic performance. Aziridine 3, 6, 7, 80-82 were synthesised in the presence of catalyst 79 and the study of the reaction scope revealed that electron rich substrates were better converted into desired products than the electron deficient ones (Scheme 16).

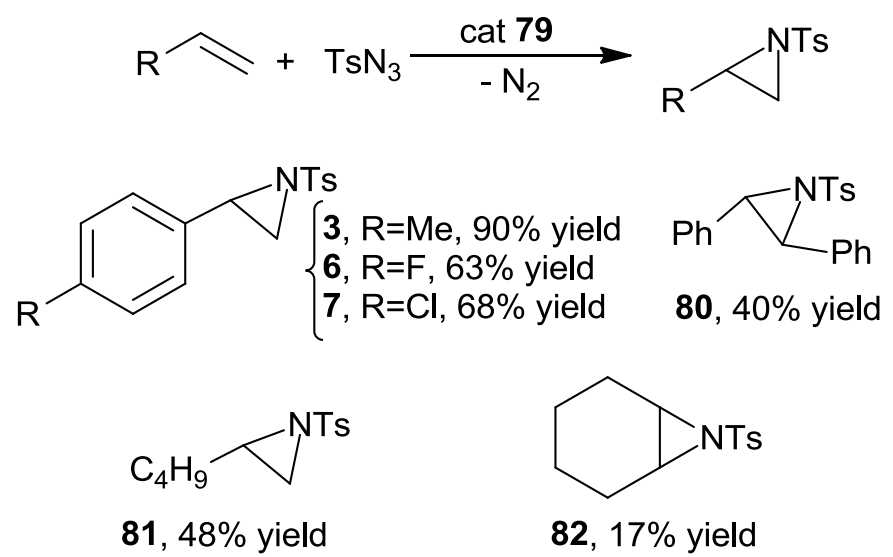

Scheme 16. Synthesis of aziridines $3,6,7,80-82$ catalysed by iron complex 79 .

J.-L. Zhang and co-authors [63] reported on the catalytic activity of iron porpholactone $\mathrm{Fe}\left(\mathrm{F}_{20}\right.$-TPPL $) \mathrm{Cl}(\mathbf{8 3})\left(\mathrm{F}_{20} \mathrm{TPPL}=\right.$ dianion of meso-tetrakis-(pentafluorophenyl) porpholactone) complex where one pyrrole of the parent porphyrin ligand was replaced by an oxazolone ring. This structural modification produced a macrocycle able to stabilise high valent metals and $\mathrm{Fe}\left(\mathrm{F}_{20}-\mathrm{TPPL}\right) \mathrm{Cl}(\mathbf{8 3})$ performed better than $\mathrm{Fe}\left(\mathrm{F}_{20} \mathrm{TPP}\right) \mathrm{Cl}(\mathbf{1})$ complex in promoting the synthesis of $\mathbf{2}$ by the reaction of styrene with $\mathrm{TsN}_{3}$. In addition, catalyst $\mathbf{8 3}$ adequately catalysed the aziridination of several alkenes with $\mathrm{TsN}_{3}$ as shown in Scheme 17. 

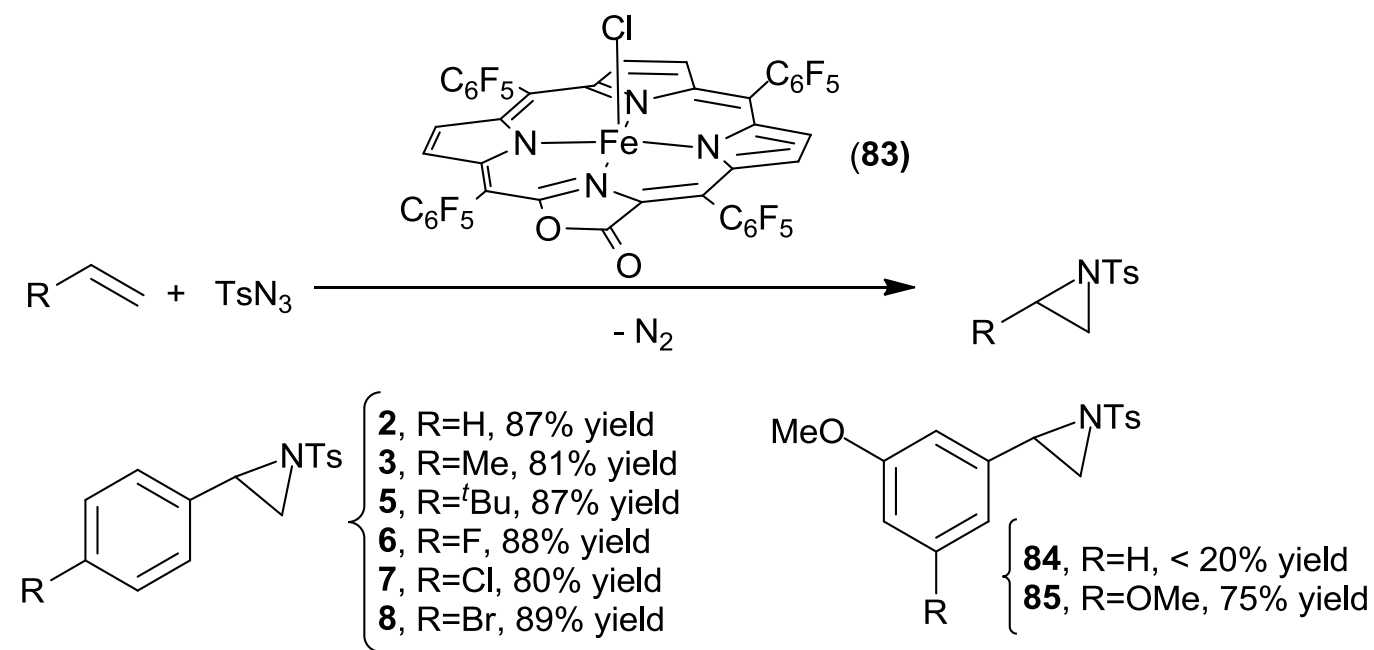<smiles></smiles>

$86,84 \%$ yield<smiles>[S-][S+]1CC1c1ccc2ccccc2c1</smiles>

$87,81 \%$ yield<smiles>[S+]=[N+]1C2CCc3ccccc3C21</smiles>

$88,58 \%$ yield

Scheme 17. Synthesis of aziridines $2, \mathbf{3}, \mathbf{5 - 8}, \mathbf{8 4 - 8 8}$ catalysed by $\mathrm{Fe}\left(\mathrm{F}_{20} \mathrm{TPPL}\right) \mathrm{Cl}(\mathbf{8 3})$.

Complex $\mathrm{Fe}\left(\mathrm{F}_{20}\right.$ TPPL)Cl (83) also catalysed the fullerene aziridination, forming the corresponding $\mathrm{C}_{60}$ aziridine (43\% yield), which represents useful starting material for the synthesis of compounds with optical and electronic applications.

\section{Metal Schiff Base Catalysts}

Metal Schiff base complexes have been found over the years to be efficient aziridination catalysts [64-68] and among employed metal complexes, ruthenium derivatives were also active in mediating asymmetric reactions $[69,70]$. The catalytic activity of ruthenium Schiff base derivatives has been mainly investigated by T. Katsuki and co-authors who have studied the reactivity of organic azides for the enantioselective aziridination of alkenes [17].

The ruthenium (II) chiral Schiff base complexes 89-91 were synthesised and tested as catalysts in the reaction of styrene with $\mathrm{TsN}_{3}$ forming 2. As reported in Scheme 18, complex 91 showed the best catalytic efficiency, which was ascribed to its pronounced chemical stability due to the presence of aryl substituents bearing chloro and trimethylsilyl groups. It was proposed that $\mathrm{C}-\mathrm{H}$ amination processes, at the expense of ligand aryl substituents, were responsible for the catalyst deactivation and that decomposition pathways were limited by using bulky and robust chloro and trimethylsilyl groups as in catalyst $\mathbf{9 1 .}$ 


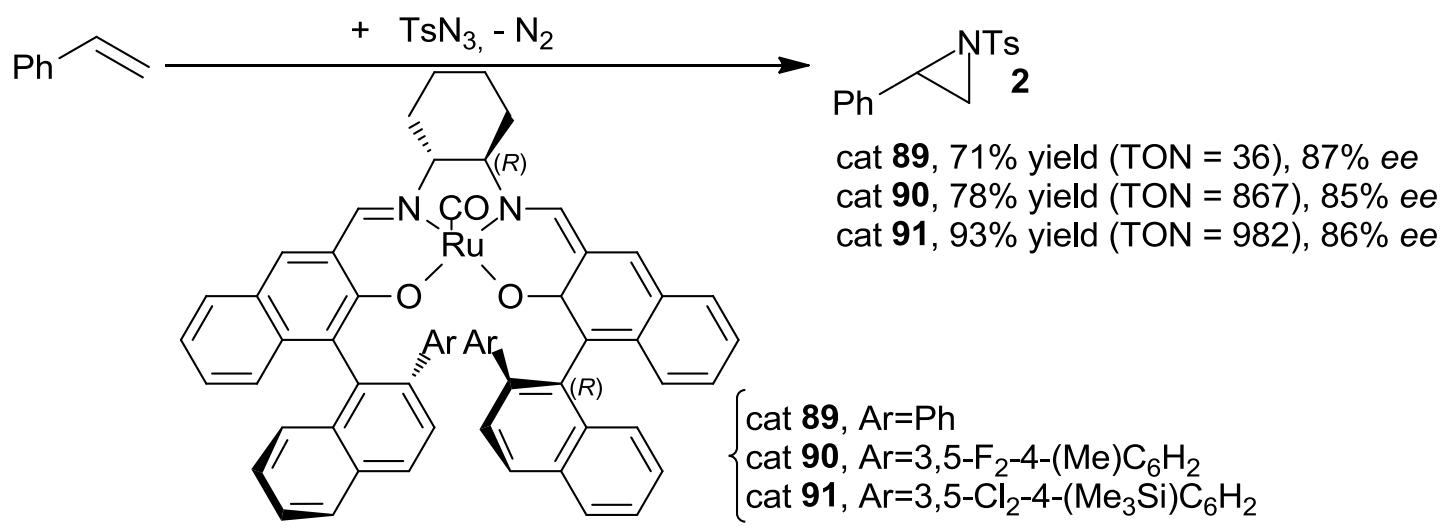

Scheme 18. Synthesis of aziridine 2 catalysed by ruthenium Schiff base complexes 89-91.

The best catalysts 90 and 91 were employed by T. Katsuki and co-authors [71, 72] to study the reaction scope by testing several alkenes with $\mathrm{TsN}_{3}, p-\mathrm{NsN}_{3}, o-\mathrm{NsN}_{3}(\mathrm{Ns}=$ nitrobenzensulfonyl) and $\mathrm{SESN}_{3}$ (SES = 2-(trimethylsilyl)ethanesulfonyl) Scheme 19.
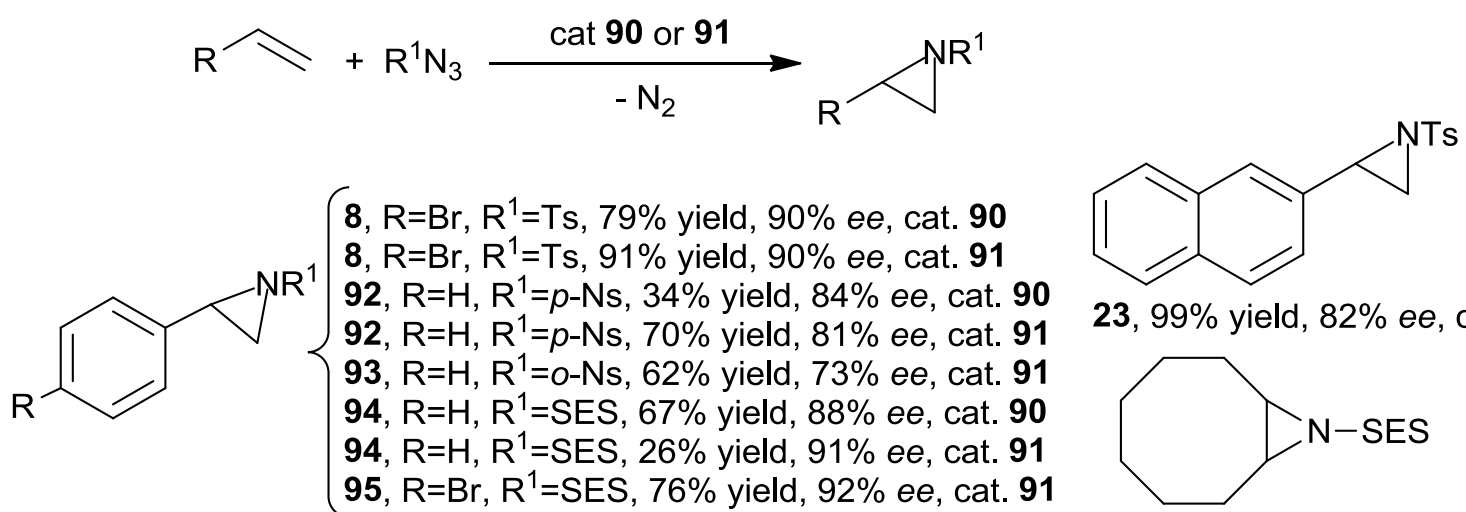

23, $99 \%$ yield, $82 \%$ ee, cat. 91<smiles>[13CH3]C1CN1[TeH2]</smiles><smiles>c1ccc2c(c1)CC1NC21</smiles>

$\{55,20 \%$ yield, $86 \%$ ee, cat. $90\{97, R=T s, 48 \%$ yield, >99\% ee, cat. 91

55, 64\% yield, $84 \%$ ee, cat. 91 \{88, R=SES, $65 \%$ yield, $98 \%$ ee, cat. 91

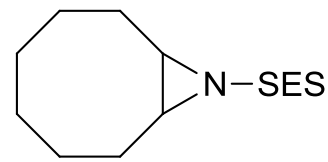

$96,28 \%$ yield, $77 \%$ ee, cat. 91

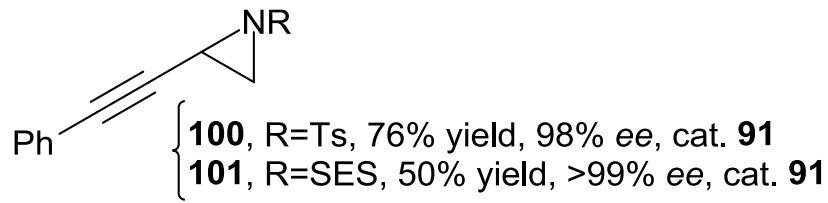<smiles>O=C(Oc1ccccc1)C1CN1S#[SH]</smiles>

99, $81 \%$ yield, $>99 \%$ ee, cat. 91<smiles>CON(Cc1ccccc1)C(=O)C1CN1S#[SH]</smiles>

$102,85 \%$ yield, $>99 \%$ ee, cat. 91

Scheme 19. Synthesis of aziridines $8,23,55,92-102$ catalysed by complexes 90 and 91 .

As reported above, $\mathrm{SESN}_{3}$ revealed to be a very effective aminating agent and this is remarkable in view of the chemical facility in removing the SES protecting group to afford unprotected chiral aziridine molecules. 
Concerning the aziridination mechanism, the formation of ruthenium (IV) imido active species was suggested and the observed stereochemistry was attributed to an alkene approach where, in order to minimise steric hindrances, the double bond of the starting material was arranged along the bond between the ruthenium centre and the Schiff base nitrogen atom.

Catalyst 91 was also employed [73] for the enantioselective aziridination of various vinyl ketones by using $\mathrm{SESN}_{3}$ as the nitrene precursor. Aziridines 103-111 were formed in high yields, good regioselectivity and almost complete enantioselectivity (Scheme 20). The reported methodology is of particular importance because the asymmetric aziridination of vinyl ketones represents the key step of the dopamin $\mathrm{D}_{3}$ receptor agonist (+)-PD 128907 synthesis.
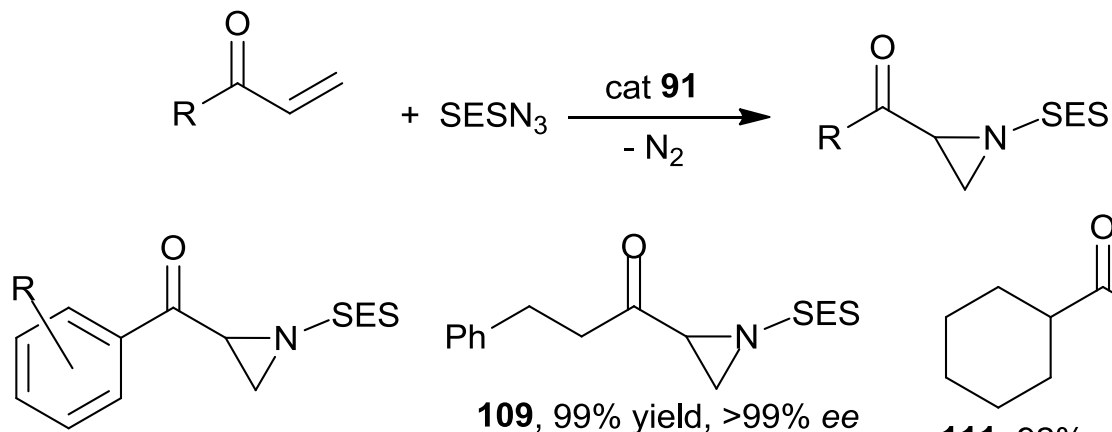<smiles></smiles><smiles>O=C(C1CCCCC1)C1CN1S#[SH]</smiles>
$\left\{\begin{array}{l}\text { 103, } \mathrm{R}=\mathrm{H}, 99 \% \text { yield, }>99 \% \text { ee } \\ \text { 104, } \mathrm{R}=p-\mathrm{Cl}, 96 \% \text { yield, }>99 \% \text { ee } \\ 105, \mathrm{R}=m-\mathrm{Cl}, 96 \% \text { yield, }>99 \% \text { ee } \\ 106, \mathrm{R}=0-\mathrm{Cl}, 98 \% \text { yield, }>99 \% \text { ee } \\ 107, \mathrm{R}=p-\mathrm{OMe}, 92 \% \text { yield, }>99 \% \text { ee } \\ 108, \mathrm{R}=m-\mathrm{OMe}, 99 \% \text { yield, }>99 \% \text { ee }\end{array}\right.$<smiles>[13CH3]N1C2C(C(=O)/C=C/c3ccccc3)C21</smiles>

Scheme 20. Complex 91-catalysed synthesis of aziridines 103-111

Considering that a ruthenium-imido catalytic intermediate, of a general formula $(\mathrm{SB})(\mathrm{CO}) \mathrm{Ru}=\mathrm{NSO}_{2} \mathrm{R}$, was supposed to act as an electrophilic species, T. Katsuki and co-authors [74] reported the synthesis of complex 112 where aryl substituents bear $\mathrm{CF}_{3}$ groups. The authors proposed that the positive interaction between antibonding C-F orbitals and the sulfonyl oxygen atom of the ruthenium imido moiety enhanced the electrophilic nature of the nitrogen atom of the active $\mathrm{Ru}=\mathrm{NSO}_{2} \mathrm{R}$ functionality, with a consequent improvement of the catalytic performance (Figure 4). 


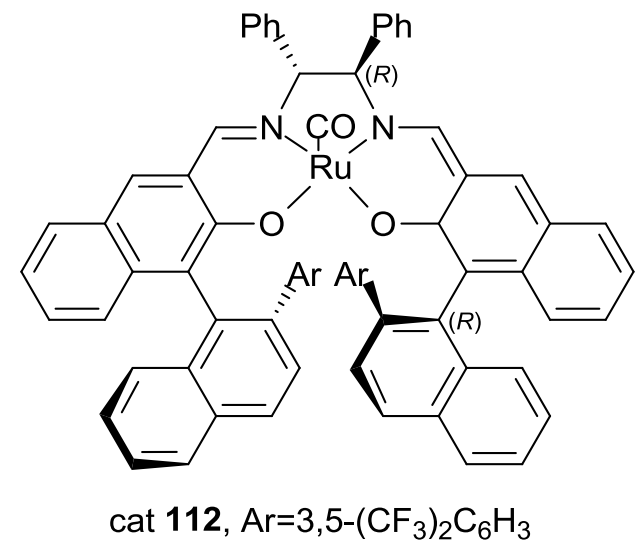

Figure 4. Structure of ruthenium catalyst 112

The catalytic efficiency of complex $\mathbf{1 1 2}$ was confirmed by its capacity to efficiently promote the aziridination of both non-conjugated and aromatic alkenes by using $\mathrm{SESN}_{3}$ as the nitrogen source (Scheme 21).

$$
\mathrm{R} \curvearrowright+\operatorname{SESN}_{3} \frac{\text { cat } 112}{-\mathrm{N}_{2}}
$$

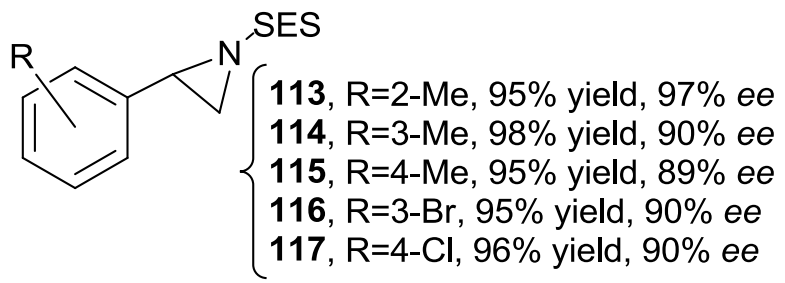<smiles>CC1C(c2ccccc2)N1S#[SH]</smiles>

$119,72 \%$ yield, $99 \%$ ee<smiles>S=[S-]N1C2Cc3ccccc3C21</smiles>

98, $66 \%$ yield, $97 \%$ ee<smiles>[R]C1CN1S#[SH]</smiles><smiles>[Mg]O[Mg][Os]</smiles><smiles></smiles>

$120,45 \%$ yield, $99 \%$ ee<smiles>S=[S-]N1CC1Br</smiles>

$121,91 \%$ yield, $90 \%$ ee<smiles>[R]C(C)=CCC1CN1S#[SH]</smiles>

123, $\mathrm{n}=3, \mathrm{R}=\mathrm{Me}, 54 \%$ yield, $89 \%$ ee

$\{124, n=1, R=H, 58 \%$ yield, $91 \%$ ee<smiles>[13CH3]C1CN1S#[SH]</smiles>

$122,74 \%$ yield, $99 \%$ ee<smiles></smiles>

$\{125, \mathrm{R}=\mathrm{Br}, 95 \%$ yield, $91 \%$ ee 126, $\mathrm{R}=\mathrm{OBn}, 65 \%$ yield, $87 \%$ ee

Scheme 21. Synthesis of aziridines 98, 113-126 catalysed by complex 112

To the best of our knowledge, since 2006 iron Schiff base complexes have not been used as aziridination catalysts and consequently, they have not been discussed. 


\section{Metal Carbene Catalysts}

Carbene ligands behave as $\sigma$-donor ligands which can substitute typical two electron donor ligands (amines, ethers and phosphanes) in order to form metal complexes largely used to promote homogeneous catalytic reactions including aziridinations of alkenes by organic azides.

D. M. Jenkins and co-authors [75, 76] reported the synthesis of macrocyclic tetracarbene iron complex $\left[(\mathrm{TC}) \mathrm{Fe}(\mathrm{NCMe})_{2}\right]\left(\mathrm{PF}_{6}\right)_{2}(\mathbf{1 2 7})(\mathrm{TC}=$ tetracarbene ligand $)$, which efficiently performed in the catalytic reaction between aryl azides and poor reactive alkenes, such as aliphatic and not to mention tetrasubstituted alkenes (Scheme 22).

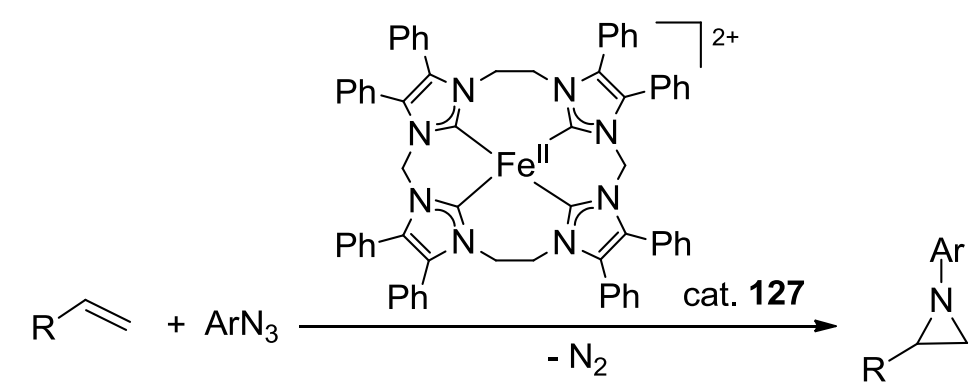

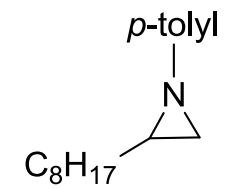

$128,82 \%$ yield<smiles>[18OH]C1CN1c1ccc(C(F)(F)F)cc1</smiles>

$131,37 \%$ yield

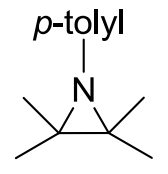

$129,20 \%$ yield

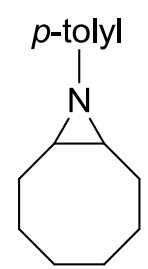

$132,97 \%$ yield<smiles></smiles>

$130,30 \%$ yield

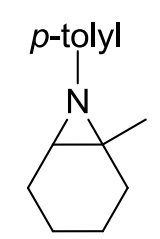

$133,39 \%$ yield

Scheme 22. Catalyst 127-catalysed synthesis of aziridines 128-133

The authors attributed the activity of catalysts $\mathbf{1 2 7}$ to the presence of the strong $\sigma$-donor 18 -atom ringed tetracarbene ligand, which stabilised a putative $\mathrm{Fe}^{\mathrm{IV}}$-imido active intermediate by increasing the electron density at the active metal centre. The robustness of the catalyst was investigated by performing consecutive catalytic reactions, which furnished desired compounds with similar effectiveness for four successive runs.

The supposed catalytically active $[(\mathrm{TC}) \mathrm{Fe}=\mathrm{NAr}]\left(\mathrm{PF}_{6}\right)_{2}(\mathrm{Ar}=p$-tolyl $)(\mathbf{1 3 4})$ intermediate was not isolated but its formation was supported by the ESI-MS analysis of the stoichiometric reaction of 
complex 127 with 4-trifluoromethylphenyl azide, which revealed the presence of $\left[(\mathrm{TC}) \mathrm{Fe}=\mathrm{NAr}{ }^{\prime}\right]\left(\mathrm{PF}_{6}\right)_{2}\left(\mathrm{Ar}{ }^{\prime}=4-\mathrm{CF}_{3} \mathrm{C}_{6} \mathrm{H}_{4}\right)$ compound.

The formation of iron-imido derivatives achieved through the reaction of iron (II) tetracarbene derivatives with aryl azides was supported by the isolation of iron tetrazene complex (135) from the reaction of 127 with an excess of p-tolyl azide (Scheme 23) [77]. Complex 135 was fully characterised including the determination of its molecular structure by X-ray spectroscopic analysis; collected data also supported the presence of an iron (IV) metal centre.

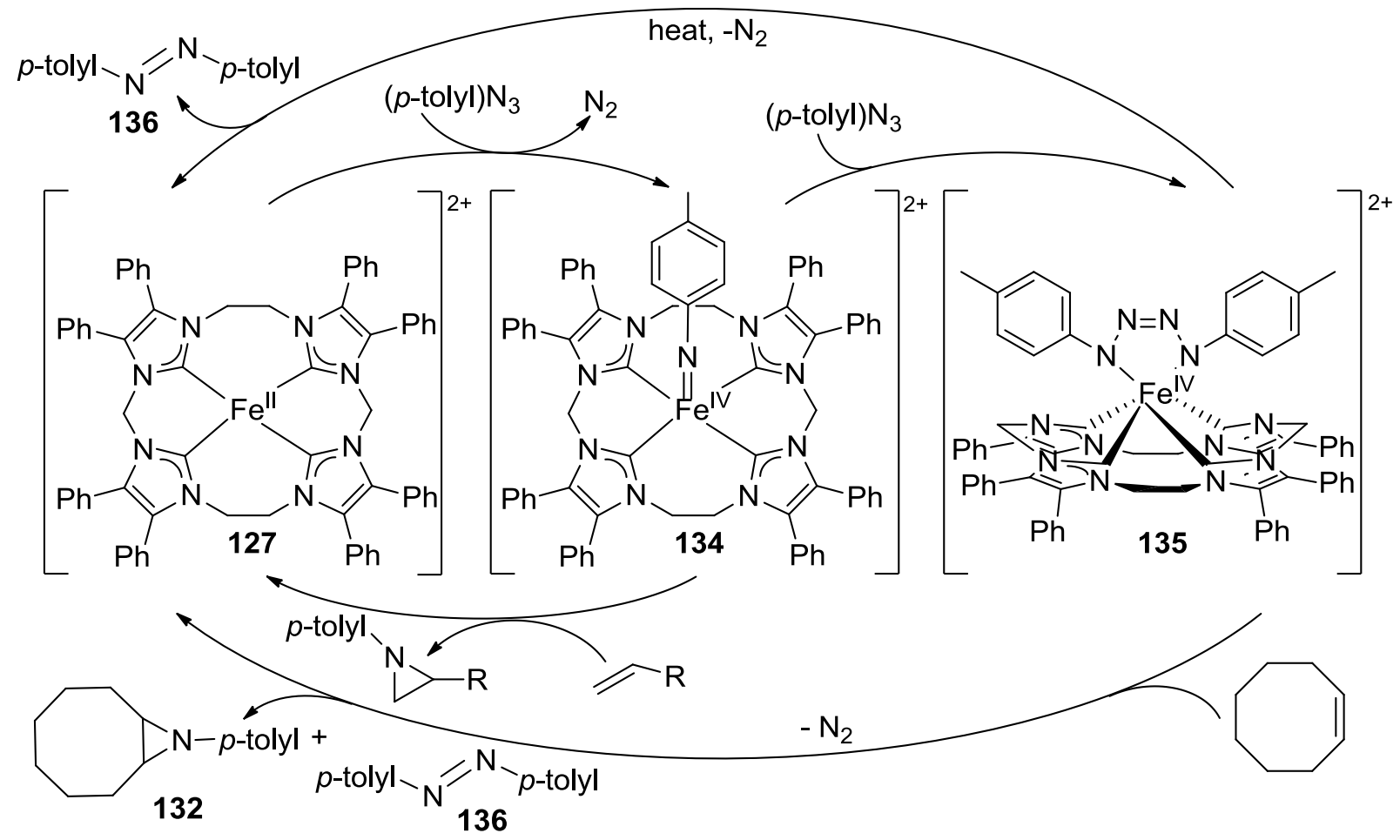

Scheme 23. Synthesis and reactivity of iron (IV) tetrazene complex 135.

The authors suggested that the reaction of $\mathbf{1 2 7}$ with another azide molecule, in the absence of alkene substrate, was responsible for the synthesis of 135 , which, when treated at $85^{\circ} \mathrm{C}$, can regenerate 127 as well as 4-4'-dimethylazobenzene (136). Complex 135 efficiently catalysed the aziridination of cyclooctene by $p$-tolyl azide (77\% yield) and was also active in the stoichiometric transfer of the nitrene functionality to an alkene. In fact, when 135 was heated at $90^{\circ} \mathrm{C}$ in neat cyclooctene, a mixture of corresponding aziridine 132 and 4-4'-dimethylazobenzene 136 was formed. It should be noted that this is the first example of the formation of an aziridine molecule from the reaction of a metallotetrazene compound with an alkene.

D. M. Jenkins and co-authors also developed a second-generation aziridination catalyst supported by a borate-based dianionic macrocyclic tetracarbene ligand [78] in which the higher $\sigma$-donor strength of the ligand favoured the formation of the iron (IV) imide intermediate. The new 
macrocyclic tetracarbene iron (II) complex 137 mediated the aziridination of aliphatic alkenes by aryl azides in higher yields than those obtained by employing $\mathbf{1 2 7}$ as the catalytic species. In fact, compound 128 was obtained in a yield of $95 \%$ versus $82 \%$ when the reaction was performed in the presence of 137 instead of 127 (compare Schemes 23 and 24). In addition, catalyst 137 was also active in promoting the aziridination of aliphatic alkenes by using alkyl azides, which were generally poorly reactive with other catalytic systems (Scheme 24).

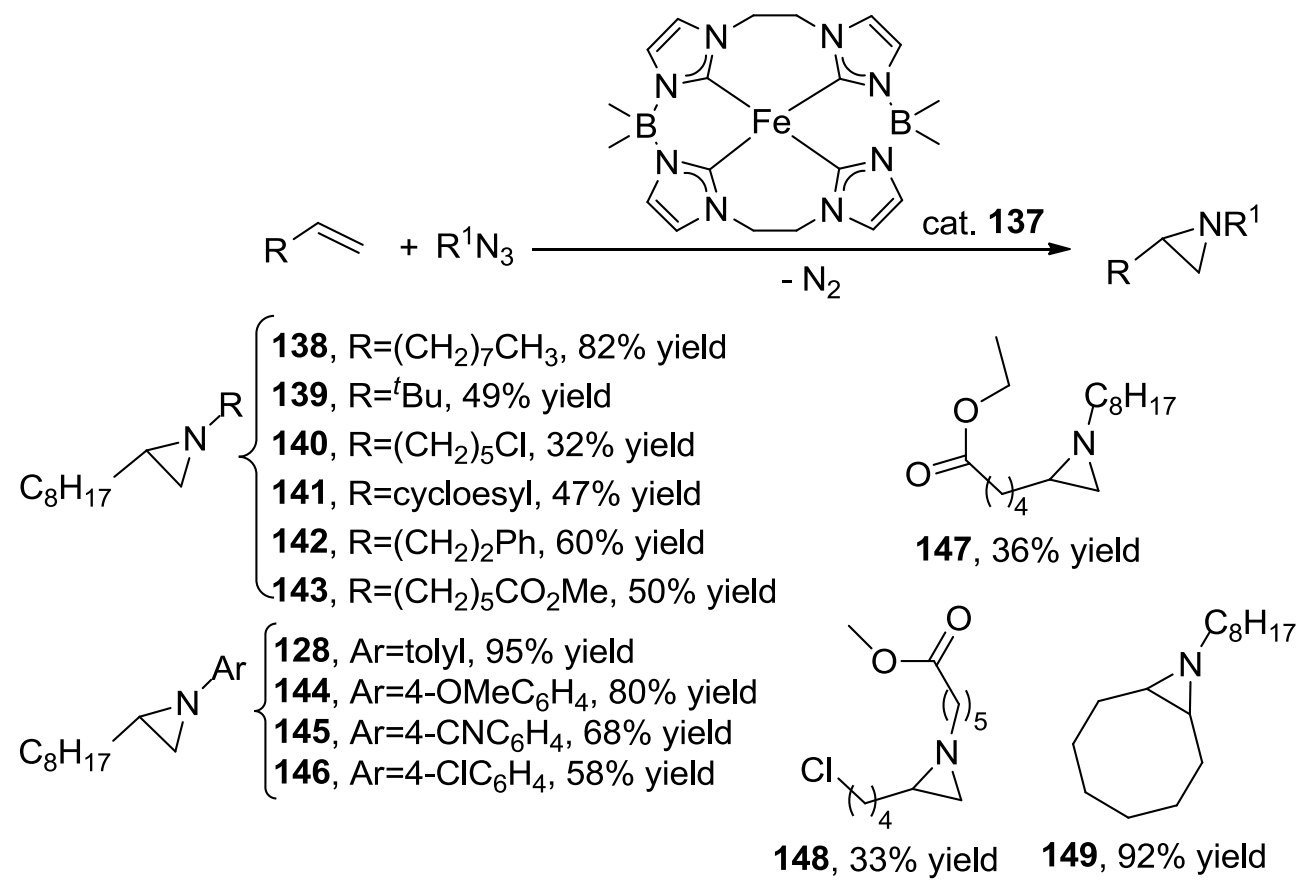

Scheme 24. Synthesis of aziridines 128, 138-149 catalysed by complex 137.

Complex 137 was also a competent catalyst in intramolecular aziridinations, which afforded rare tertiary bicyclic aziridines $\mathbf{1 5 0}$ and $\mathbf{1 5 1}$ (Scheme 25).

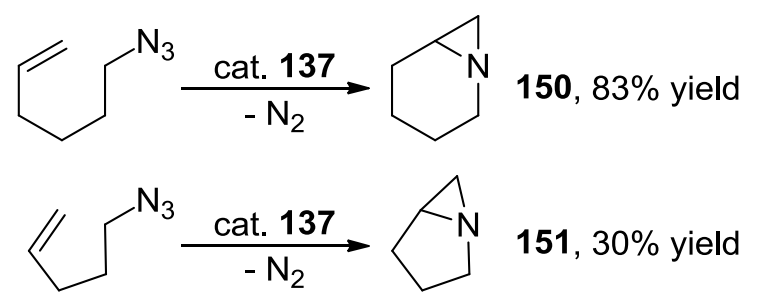

Scheme 25. Synthesis of bicyclic aziridines 150 and 151 by complex 137-catalysed intramolecular aziridinations.

Bulky tris(carbene)borate ligands were used by J. M. Smith and co-authors [79] to synthesise iron (IV) nitride complexes 152 and 153, which showed a very interesting reactivity towards alkenes in forming iron (II) aziridino complexes 154-163 (Scheme 26). All complexes were fully 
characterised and the molecular structure of 154, 162 and 163 were solved by the single-crystal $\mathrm{X}$-ray diffraction.

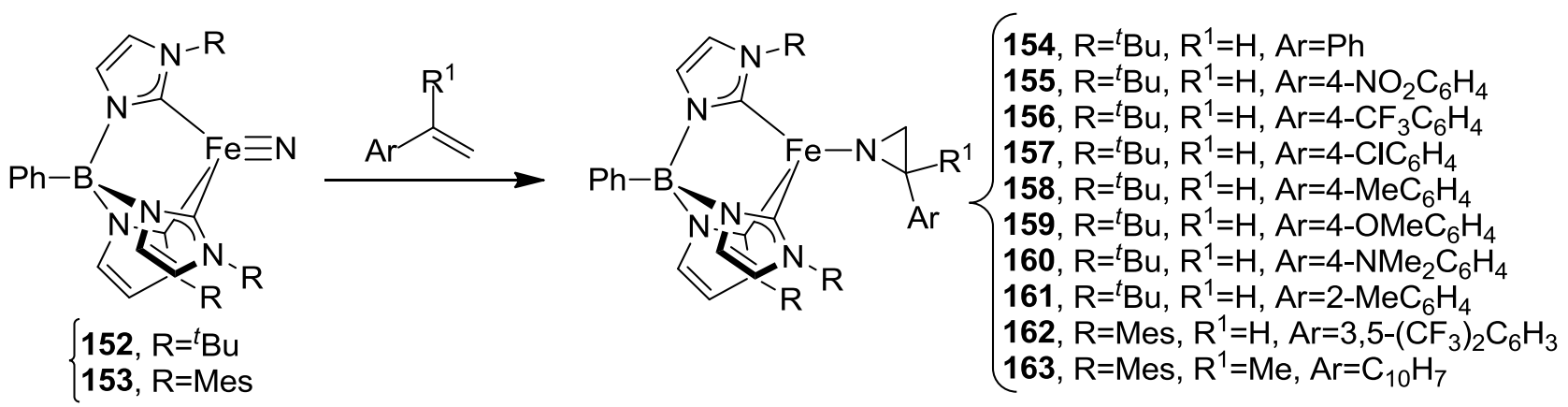

Scheme 26. Synthesis of iron (II) aziridino complexes 154-163.

Interestingly, complex 154, when treated with para-substituted styrenes, was involved in aziridine cross-metathesis reactions yielding aziridino complexes 164-166 as well as styrene free (Scheme 27).

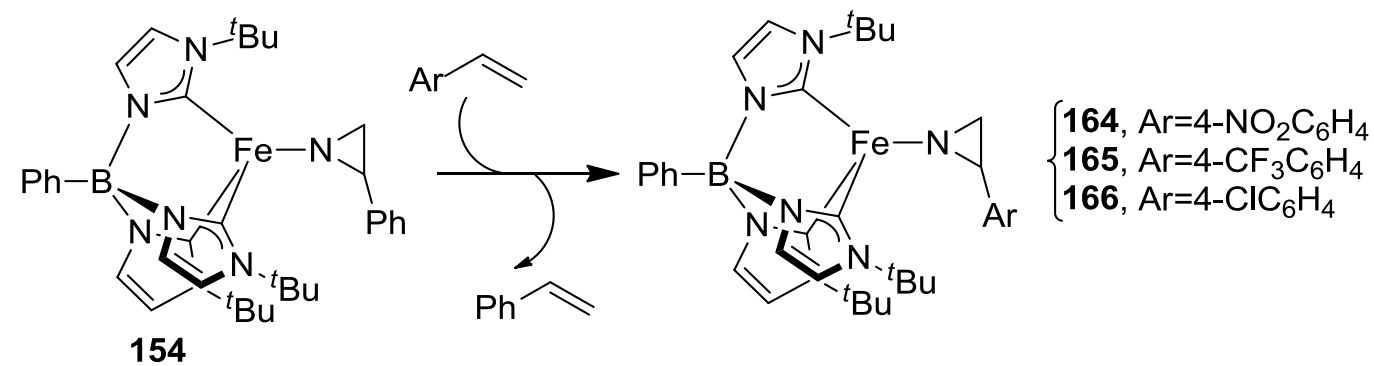

Scheme 27. Cross-metathesis reactions forming complexes 164-166

The reaction reported in Scheme 27 was productive with electron poor alkenes, whereas no reaction was observed when $\mathbf{1 5 4}$ reacted with more electron rich styrenes. It should be noted that a catalytic application of complexes 152-166 has not yet been reported.

\section{Iron Complexes of Other Nitrogen Ligands}

Considering that no other ruthenium complexes, except those reported in previous sections, have been tested since 2006 as aziridination catalysts, this section only deals with the catalytic use of iron complexes not categorised in this review up to now. Due to the great structural diversity of engaged ligands, we have referred to iron complexes in a chronological order as they appeared in different papers we have used for this review. It should be noted that all the surveyed articles employed iminoiodinane compounds as aziridination agents. 
J. A. Halfen and co-authors [80] reported in 2007 the synthesis of two iron complexes $\left[\left(\mathrm{Me}_{5}\right.\right.$ dien $\left.) \mathrm{Fe}\left(\mathrm{O}_{3} \mathrm{SCF}_{3}\right)_{2}\right] \quad\left(\mathrm{Me}_{5}\right.$ dien $=1,1,4,7,7$-pentamethyldiethylenetriamine $)$ (167) and $\left[\left({ }^{i} \mathrm{Pr}_{3} \mathrm{TACN}\right) \mathrm{Fe}\left(\mathrm{O}_{3} \mathrm{SCF}_{3}\right)_{2}\right]\left({ }^{i} \mathrm{Pr}_{3} \mathrm{TACN}=\right.$ 1,4,7-triisopropyl-1,4,7-triazacyclononane) (168), which mediated the aziridination of styrene by $\mathrm{PhI}=\mathrm{NT}$ s forming compound $\mathbf{2}$. In order to evaluate the influence of electronic and structural characteristics of ligands on the catalytic efficiency, the activity of 167 and 168 complexes was compared to that of already published [L ${ }^{8} \mathrm{py}_{2} \mathrm{FeOTf}$ OTf (169) [81], [TPAFe $\left.\left(\mathrm{CH}_{3} \mathrm{CN}\right)_{2}\right]_{\mathrm{OTf}}$ (170) [82] and [N4pyFe $\left(\mathrm{CH}_{3} \mathrm{CN}\right) \mathrm{OTf}_{2}$ (171) [83] complexes (Scheme 28). Achieved results indicated that the presence of two cis labile coordination sites on the iron centre was necessary for an efficient catalytic activity and in fact, the poorest yields were obtained in the presence of catalysts 169 and 171 because of either two trans labile sites (complex 169) or only a single site (complex 171) were available for the coordination of reagent species.

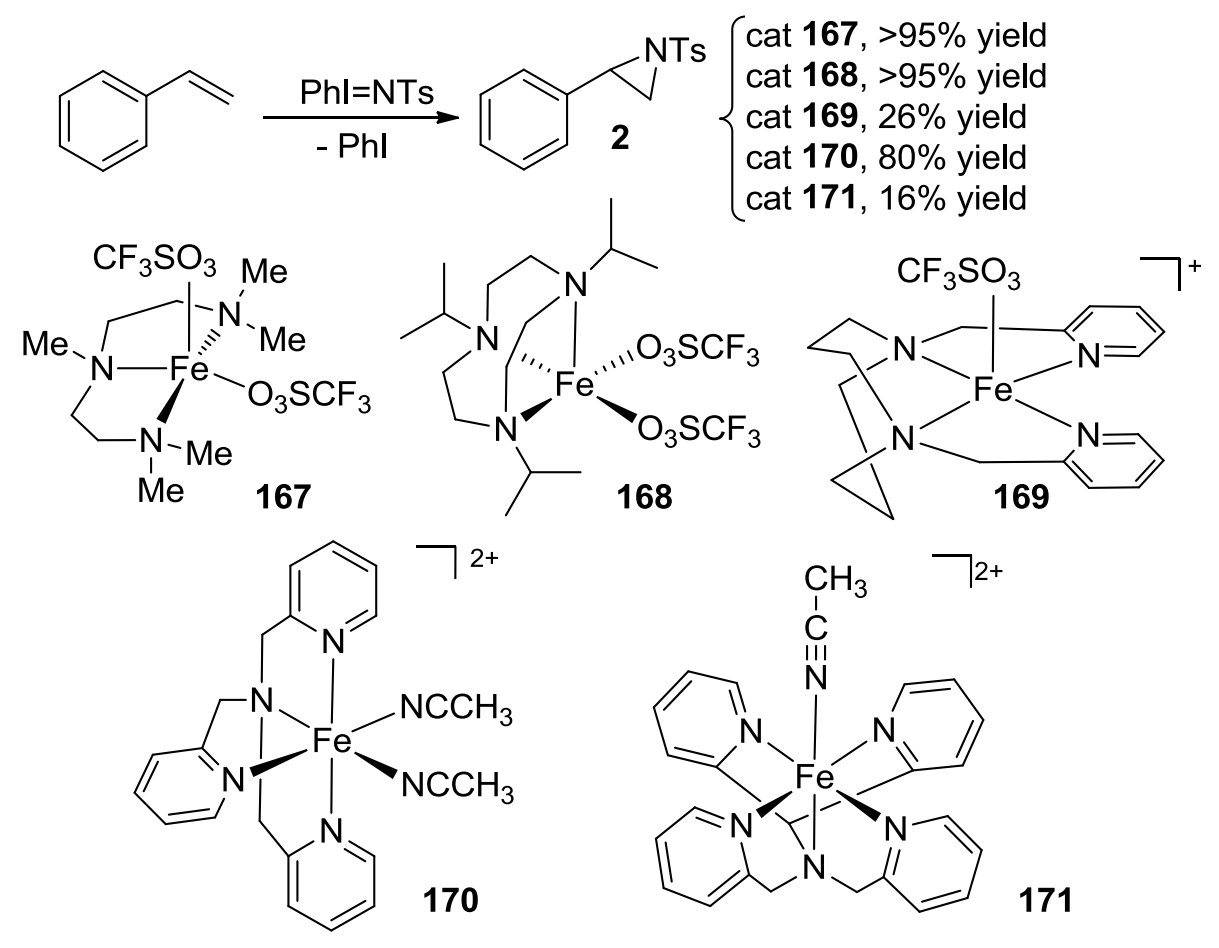

Scheme 28. Synthesis of compound 2 mediated by catalysts 167-171.

The 167-catalysed aziridination of cis-1-phenylpropene yielded the corresponding aziridine 172 in a syn/anti ratio, which was dependent on the coordination capability of the reaction solvent and steric characteristic of the employed catalyst. When the non-coordinating $\mathrm{CH}_{2} \mathrm{Cl}_{2}$ solvent was replaced by the coordinating $\mathrm{CH}_{3} \mathrm{CN}$ solvent, the syn/anti ratio decreased from 9:1 to 2:1 indicating that different reaction mechanisms occurred in the two cases (Scheme 29). The same trend was observed when the reaction was performed in the presence of the more hindered catalyst $\mathbf{1 6 8}$ where 
the syn/anti ratio of 2:1 was obtained in $\mathrm{CH}_{2} \mathrm{Cl}_{2}$, whereas an equimolar syn/anti ratio was formed in $\mathrm{CH}_{3} \mathrm{CN}$ as the reaction solvent.

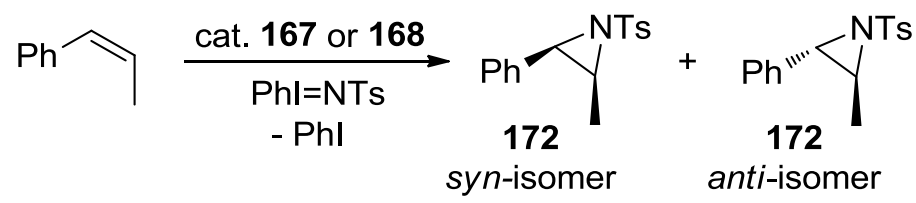

Scheme 29. Synthesis of aziridine 172 mediated by catalyst 167 or 168 .

Considering that collected data indicated that both the presence of a coordinating solvent and/or a sterically encumbered ligand were responsible for a decrease of the reaction stereospecificity, a DFT study was performed to rationalise the stereochemical outcome of the 167-catalysed aziridination of cis-alkenes [84]. It was suggested that the reaction of the initial iron (II) complex 167 with $\mathrm{PhI}=\mathrm{NT}$ s yielded the imidoiron (IV) intermediate $\mathbf{A}$, from which two different pathways can start depending on the coordinating ability of the reaction solvent and the steric hindrance around the catalytically active metal centre (Scheme 30).

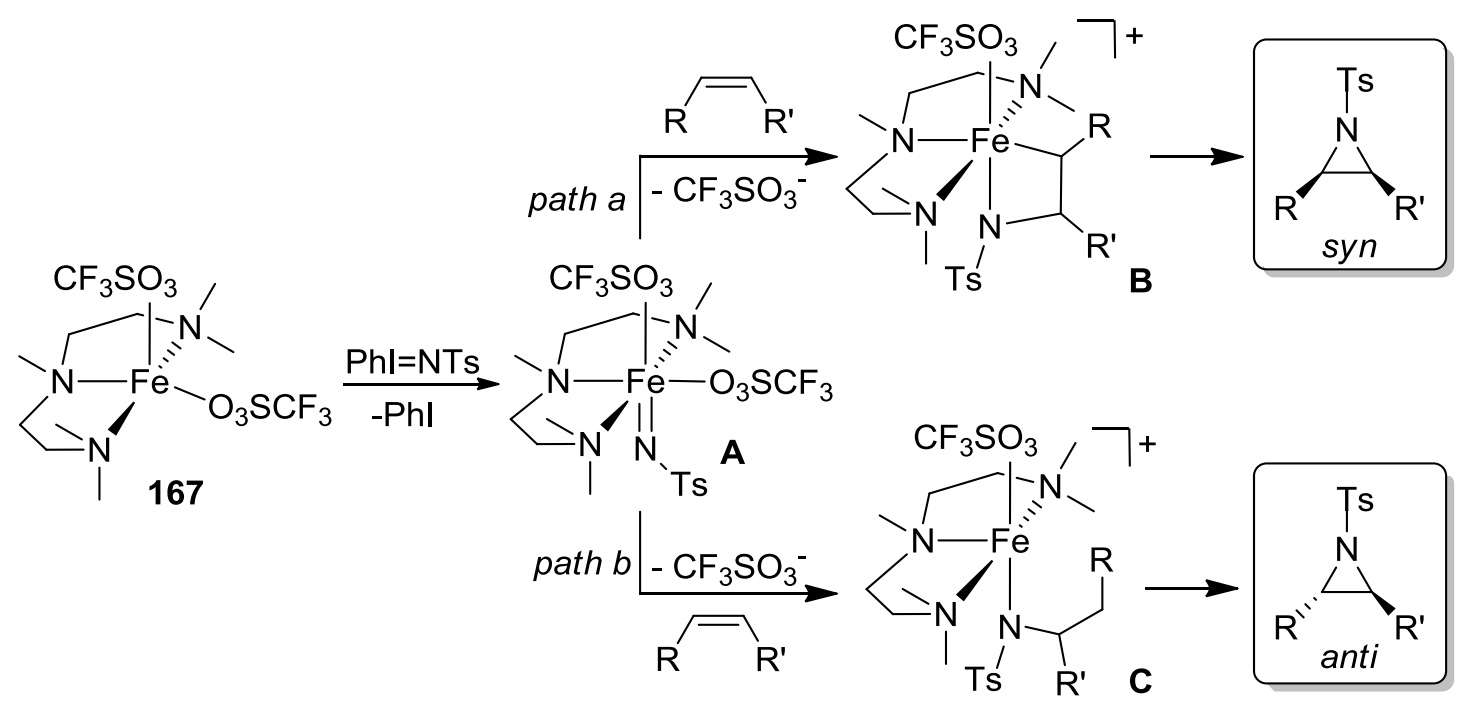

Scheme 30. Mechanistic proposal of the 167-catalysed aziridination of cis-alkenes.

The first proposed mechanism (Scheme 30, path a) consisted in the formation of the azametallacyclobutane intermediate $\mathbf{B}$ from the [2+2] cycloaddition reaction of the imidoiron (IV) precursor $\mathbf{A}$ with a cis-alkene, which led to the formation of syn-aziridine either in presence of noncoordinating solvents or when the imidoiron (IV) intermediate A was supported by low sterically hindered ligands. On the other hand, the formation of the azametallacyclobutane $\mathbf{B}$ was disfavoured by the presence of either sterically encumbered ligands, which hampered the substrate access to the metal, or coordinated solvents, which competed with the alkene for the coordination onto the iron 
centre. Thus, only one coordinating site was available on the active metal and a stepwise C-N bond formation was proposed as an alternative pathway where complex $\mathbf{C}$ was responsible for the formation of the anti-aziridine product (Scheme 30, path $b$ ). It should be note that although the cationic species $\mathbf{C}$ was reported in the manuscript, the authors stated that the stepwise process leading anti-aziridine could involve either charged or radical intermediates.

C. Bolm and co-authors [85] described the catalytic activity of iron (II) triflate $\mathrm{Fe}(\mathrm{OTf})_{2}(\mathbf{1 7 3})$ in promoting the aziridination of alkenes by $\mathrm{PhI}=\mathrm{NSO}_{2} \mathrm{Ar}$ species (Scheme 31), which in some cases was formed in situ by mixing the corresponding sulfonamide compound $\left(\mathrm{ArSO}_{2} \mathrm{NH}_{2}\right)$, either iodosylbenzene $(\mathrm{PhIO})$ or iodobenzene diacetate $\left(\mathrm{PhI}(\mathrm{OAc})_{2}\right)$ and magnesium oxide.

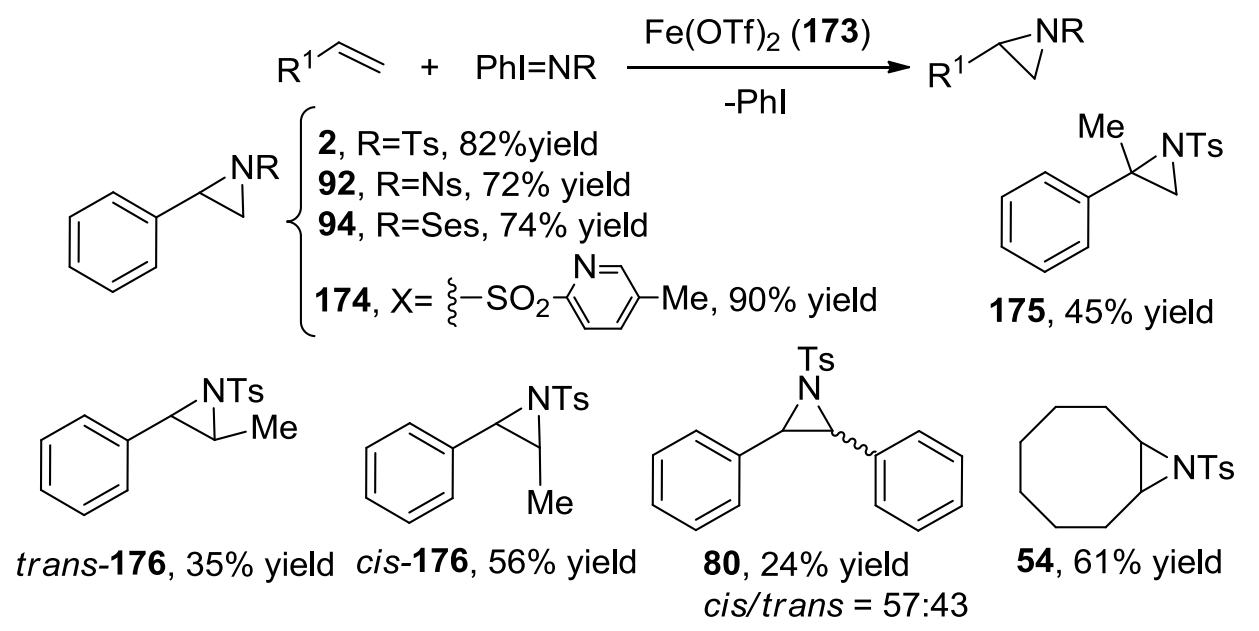

Scheme 31. $\mathrm{Fe}(\mathrm{OTf})_{2}$-catalysed synthesis of aziridines $2,54,80,92,94,174-176$.

The $\mathrm{Fe}(\mathrm{OTf})_{2}$-catalysed synthesis of compound $\mathbf{2}$ was also performed in the presence of chiral ligands 177-180 yielding $(R)$-isomer aziridines with enantioselectivities up to $40 \%$ (Scheme 32 ). 


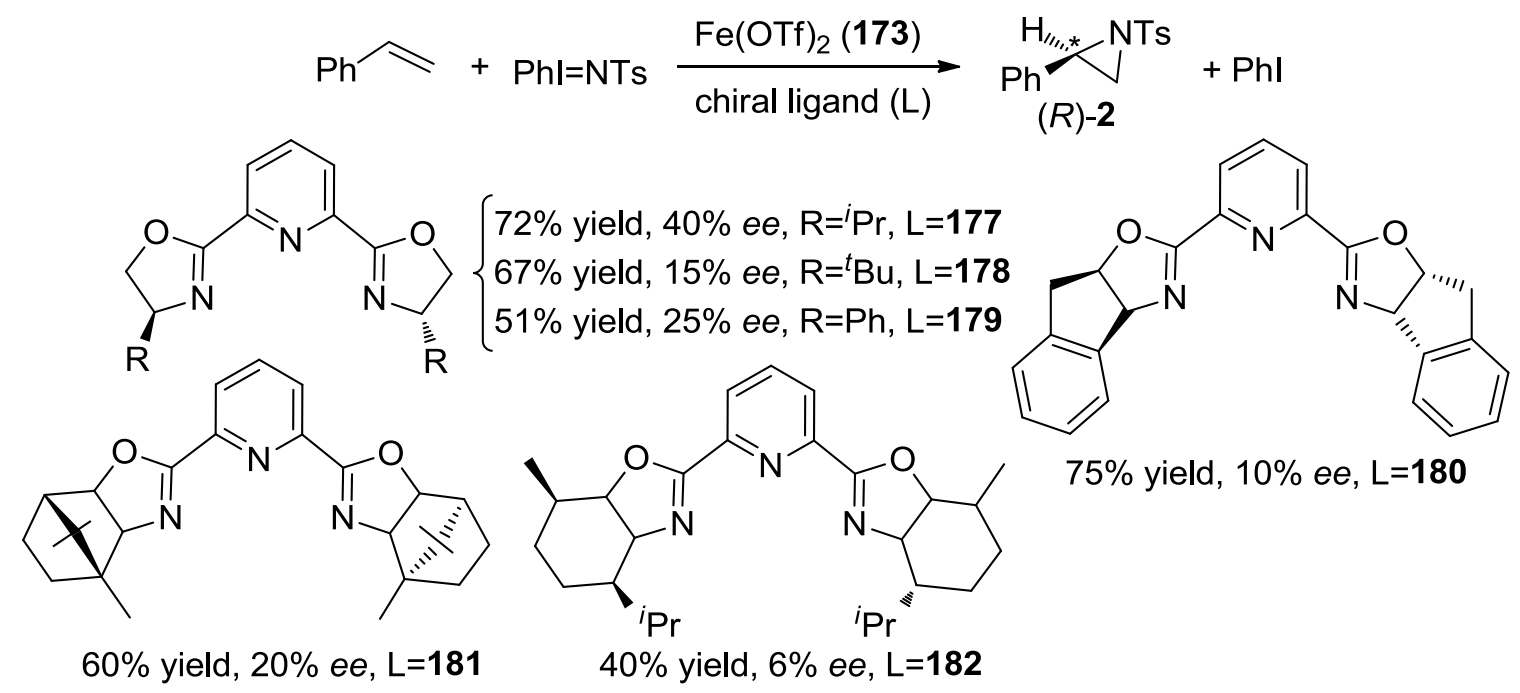

Scheme 32. Enantioselective synthesis of 2 mediated by the $\mathrm{Fe}(\mathrm{OTf})_{2} /$ chiral ligand (L) system.

The performance of $\mathrm{Fe}(\mathrm{OTf})_{2}$-mediated aziridination of alkenes was enhanced by running the reaction in the presence of an ionic liquid [86] and a pyridine type ligand. Compound 174, which was formed in $90 \%$ yield in the presence of $\mathrm{Fe}(\mathrm{OTf})_{2}$ alone, was obtained in a quantitative yield (>95\% yield) by using quinaldic acid (183) as a pyridine type ligand and ethylmethylimidazolium bis[(trifluoromethyl)sulfonyl]-amide (emim BTA) as the ionic liquid. This catalytic system was employed to synthesise aziridines 174, 184-192, as reported in Scheme 33.

It should be noted that aziridine 191 was obtained as a trans-isomer when trans-methylstyrene was used as the starting material while, if cis-methylstyrene was the reactant, a trans/cis mixture was obtained to indicate the occurrence of a radical mechanism. 


$$
\mathrm{R}^{1} \curvearrowright+\mathrm{Phl}=\mathrm{NR} \underset{\mathbf{1 8 3}, \text { emim BTA }}{\stackrel{\mathrm{Fe}(\mathrm{OTf})_{2}(\mathbf{1 7 3})}{\longrightarrow}} \mathrm{R}^{1} \overbrace{+\mathrm{Phl}}^{\mathrm{NR}}
$$<smiles>O=C(O)c1ccc2ccccc2n1</smiles><smiles>[R]c1ccc(C2CN2S(=O)(=O)c2ccc(C)cn2)cc1</smiles><smiles>Cc1ccc(S(=O)(=O)N2C(C)C2c2ccccc2)nc1</smiles>
$\left\{\begin{array}{l}174, \mathrm{R}=\mathrm{H},>95 \% \text { yield } \\ 184, \mathrm{R}=\mathrm{Me},>95 \% \text { yield } \\ 185, \mathrm{R}=\mathrm{NO}_{2}, 95 \% \text { yield } \\ 186, \mathrm{R}=\mathrm{Cl}, 36 \% \text { yield } \\ 187, \mathrm{R}=\mathrm{OAc}, 70 \% \text { yield } \\ 188, \mathrm{R}=\mathrm{CN}, 60 \% \text { yield } \\ 189, \mathrm{R}=\mathrm{CF}_{3}, 65 \% \text { yield }\end{array}\right.$<smiles>Cc1ccc(S(=O)(=O)N2CC2c2ccccc2C)nc1</smiles>

Scheme 33. Synthesis of aziridines 174, 184-192 promoted by of $\mathrm{Fe}(\mathrm{OTf})_{2} / \mathbf{1 8 3} / \mathrm{emim} \mathrm{BTA}$ catalytic system.

C. M. Che and co-authors [87] reported the use of iron (II) pyridyl complex 193 as catalyst for the intermolecular and intramolecular aziridination of various alkenes which occurred in high yields by using $\mathrm{PhI}=\mathrm{NR}$ as the nitrene transfer agent (Scheme 34). The aziridination of para-substituted electron-poor styrene derivatives was slower than that observed for para-substituted electron-rich substrates to point out that the formation of the aziridine ring was strongly influenced by the electronic characteristics of the group on the para position of styrene molecule.

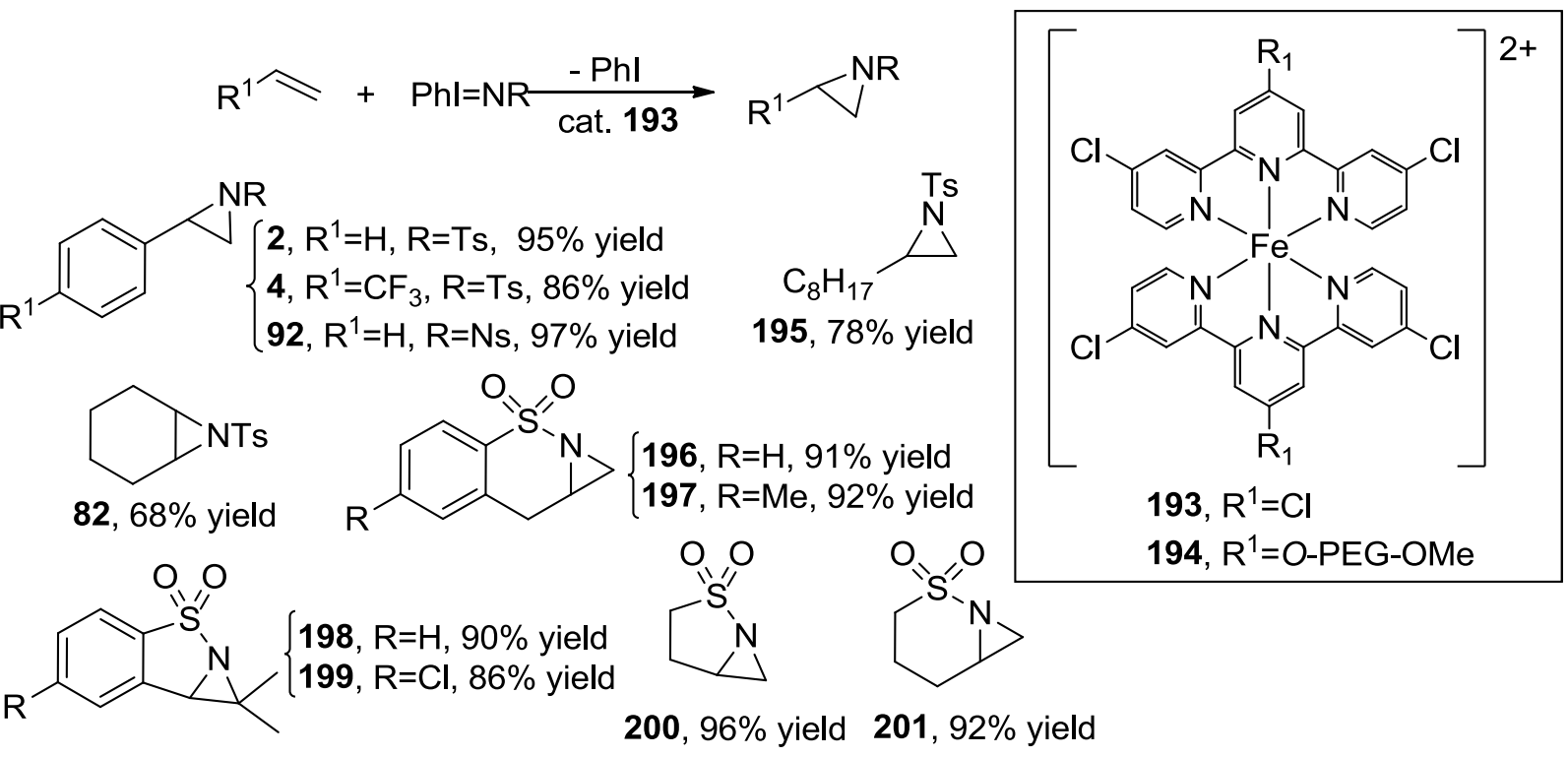

Scheme 34. Synthesis of aziridines 2, 4, 82, 92, 195-201 catalysed by 193. 
To simplify the catalyst recovery, the structure of complex 193 was modified by replacing two chlorine atoms with two $O$-PEG-OCH 3 groups and the resulting complex 194 was active for the synthesis of compound 196, which was obtained in $93 \%$ yield. When the catalytic reaction was completed, the ligand of catalyst $\mathbf{1 9 4}$ was easily recovered by a $\mathrm{H}_{2} \mathrm{O}$ extraction and it restored the initial catalyst 194 when treated in situ with $\mathrm{Fe}\left(\mathrm{ClO}_{4}\right)_{2} \cdot 6 \mathrm{H}_{2} \mathrm{O}$. This procedure was repeated few times without observing the ligand decomposition.

In 2012, Jensen and co-authors [88] screened the catalytic activity of half-sandwich scorpionate iron complexes $\left[(\mathrm{L}) \mathrm{Fe}(\mathrm{NCMe})_{3}\right]\left(\mathrm{BF}_{4}\right)_{\mathrm{n}}$ 202-205 (Figure 5) in the reaction of styrene with PhI=NTs and complex 202 performed the best yielding compound 2 in $94 \%$ yield.

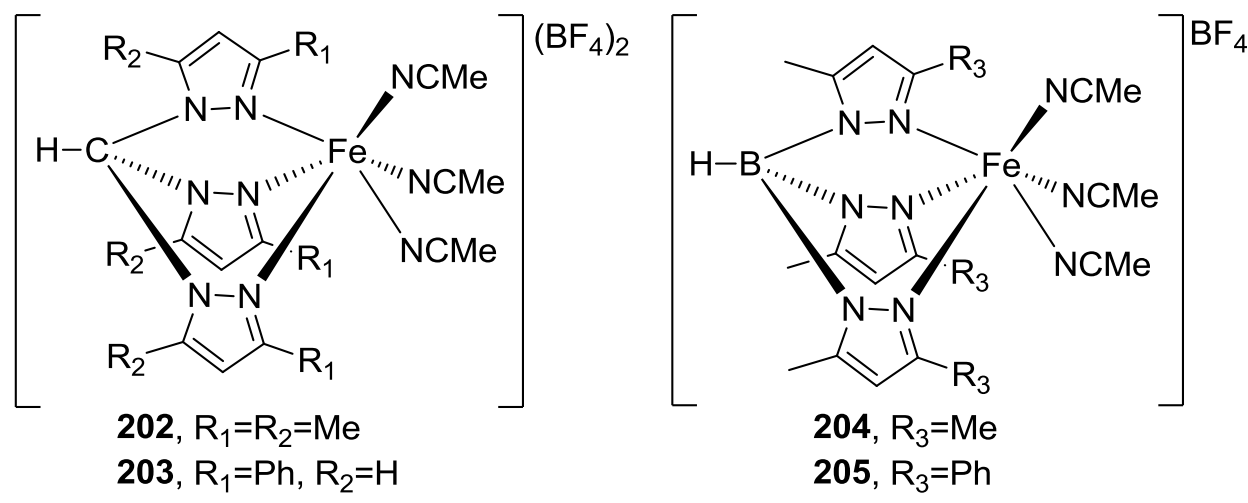

Figure 5. Structures of complexes 202-205.

Under optimised conditions iron complex 202 efficiently catalysed the aziridination of several alkenes such as cyclohexene, norborene, trans-methyl cinnamate as well as cis- and trans-stilbene (Scheme 35).

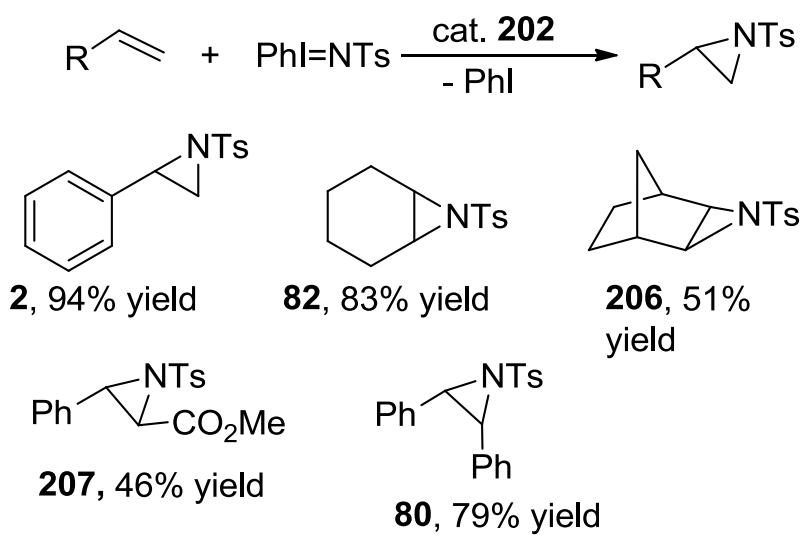

Scheme 35. Synthesis of compounds $2,80,82,206$ and 207 catalysed by iron complex 202

The study of the Hammett equation for the 202-catalysed aziridination of para-substituted styrenes suggested the formation of an electrophilic intermediate, either an adduct between iron 
complex and $\mathrm{PhI}=\mathrm{NTs}$ or an imidoiron (IV) formed as a consequence of the $\mathrm{PhI}$ release from the adduct. It was proposed that the electrophilic active intermediate $\mathbf{A}$ evolved into a $\alpha$-radicaloid intermediate $\mathbf{B}$ by the stepwise addition to styrene molecule and then a ring closure process was responsible for the formation of the aziridine molecule and restored the catalytic species (Scheme 36).

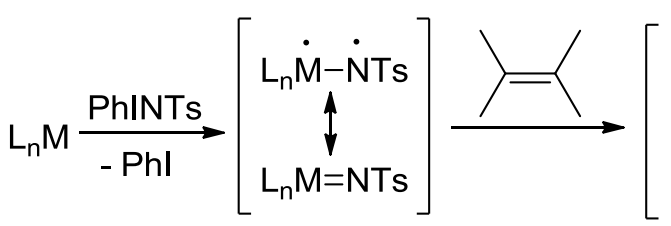

A

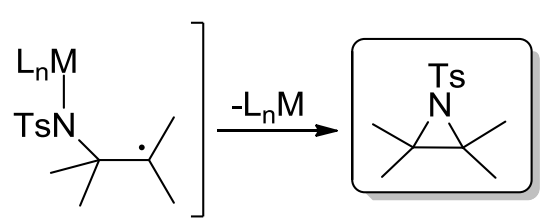

B

Scheme 36. Mechanistic proposal for the 202-catalysed aziridination

\section{Conclusion}

The goal of this review consists in the analysis of data, which have been published since 2006, about the alkene aziridination promoted by iron or ruthenium complexes. Many efforts have been undertaken to optimise synthetic procedures in order to make the one-pot reaction between an alkene and a nitrene source a valuable method to synthesise aziridine containing molecules. Even if the most reactive alkenes are usually terminal ones and contain an activating group in the alpha position with respect to the double bond, aliphatic and internal alkenes can also be converted into corresponding aziridines by choosing the opportune nitrene source and catalytic system. Even if ruthenium complexes are very active catalysts and their intrinsic chemical stability allows to study the mechanism of the nitrene transfer reaction, the scientific community is turning the attention on the use of iron catalysts to substitute noble metals with cheap first row elements. The great number of papers dealing with the use of iron complexes indicates the importance of these catalysts which combine an outstanding activity with a low-toxicity and cost effectiveness. In addition, published data outline the capability of aza-macrocyclic ligands to coordinate both iron (II) and iron (III) metal centres affording several stable complexes which can be easily handled in every laboratory under standard experimental conditions.

Considering the large application of aziridine containing compounds, it is reasonable to envisage an increasing scientific interest on the development of new and more efficient catalytic systems to produce these molecules by respecting the society's demand for sustainable organic transformations. Many efforts will be done to magnify the synthetic protocol convenience by limiting the formation of waste, maximize the atom economy, avoid the formation of toxic substances and minimize the energy requirement of chemical processes. 


\section{References}

[1] A. Nikitjuka, A. Jirgensons, Chem. Heterocycl. Compd. 49 (2014) 1544-1559.

[2] C. Botuha, F. Chemla, F. Ferreira, A. Pérez-Luna, Aziridines in Natural Product Synthesis - Heterocycles in Natural Product Synthesis, Wiley-VCH Verlag GmbH \& Co. KGaA 2011, pp. 1-39.

[3] P. Lu, Tetrahedron 66 (2010) 2549-2560.

[4] S.H. Krake, S.C. Bergmeier, Tetrahedron 66 (2010) 7337-7360.

[5] J.B. Sweeney, Chem. Soc. Rev. 31 (2002) 247-258.

[6] G.S. Singh, M. D'hooghe, N. De Kimpe, Chem. Rev. 107 (2007) 2080-2135.

[7] X.E. Hu, Tetrahedron 60 (2004) 2701-2743.

[8] A. Fingerhut, O.V. Serdyuk, S.B. Tsogoeva, Green Chemistry 17 (2015) 2042-2058.

[9] H. Ohno, Chem. Rev. 114 (2014) 7784-7814.

[10] H. Pellissier, Adv. Synth. Catal. 356 (2014) 1899-1935.

[11] G. Bencivenni, P. Righi, L. Lunazzi, S. Ranieri, M. Mancinelli, A. Mazzanti, Chirality 27 (2015) 875887.

[12] B.-N. Lai, J.-F. Qiu, H.-X. Zhang, J. Nie, J.-A. Ma, Org. Lett. 18 (2016) 520-523.

[13] N. Jung, S. Bräse, Angew. Chem. Int. Ed. 51 (2012) 5538-5540.

[14] J.W.W. Chang, T.M.U. Ton, P.W.H. Chan, Chem. Rec. 11 (2011) 331-357.

[15] H. Jiang, X.P. Zhang, E.M. Carreira, H. Yamamoto, 5.6 Oxidation: $C-N$ Bond Formation by Oxidation (Aziridines), Comprehensive Chirality, Elsevier, Amsterdam, 2012, pp. 168-182.

[16] S. Minakata, Acc. Chem. Res. 42 (2009) 1172-1182.

[17] T. Uchida, T. Katsuki, Chem. Rec. 14 (2014) 117-129.

[18] D. Intrieri, P. Zardi, A. Caselli, E. Gallo, Chem. Commun. 50 (2014) 11440-11453.

[19] S. Bräse, K. Banert, Editors, Organic Azides: Syntheses and Applications, John Wiley \& Sons Ltd. 2010.

[20] L. Yu, Curr. Org. Chem. 20 (2016) 19-28.

[21] A. Correa, O. García Mancheño, C. Bolm, Chem. Soc. Rev. 37 (2008) 1108-1117.

[22] M.J. Ingleson, R.A. Layfield, Chem. Commun. 48 (2012) 3579-3589.

[23] T.W.-S. Chow, G.-Q. Chen, Y. Liu, C.-Y. Zhou, C.-M. Che, Pure Appl. Chem. 84 (2012) 1685-1704.

[24] D. Intrieri, D.M. Carminati, E. Gallo, Recent Advances in Metal Porphyrinoid-Catalyzed Nitrene and Carbene Transfer Reactions, in: K.M.S. Edited by Kadish, Kevin M.; Guilard, Roger (Ed.) Handbook of Porphyrin Science, World Scientific Publishing Co. Pte. Ltd., 2016, pp. 1-99.

[25] B.J. Anding, L.K. Woo, An overview of metalloporphyrin-catalyzed carbon and nitrogen group transfer reactions, in: K.M.S. Edited by Kadish, Kevin M.; Guilard, Roger (Ed.) Handbook of Porphyrin Science World Scientific Publishing Co. Pte. Ltd., 2012, pp. 145-319.

[26] J.V. Ruppel, K.B. Fields, N.L. Snyder, X.P. Zhang, Metalloporphyrin-catalyzed asymmetric atom/group transfer reactions, in: K.M.S. Edited by Kadish, Kevin M.; Guilard, Roger (Ed.) Handbook of Porphyrin Science World Scientific Publishing Co. Pte. Ltd., 2010, pp. 1-84.

[27] D. Mansuy, J.P. Mahy, A. Dureault, G. Bedi, P. Battioni, J. Chem. Soc., Chem. Commun. (1984) 11611163.

[28] J.P. Mahy, P. Battioni, D. Mansuy, J. Am. Chem. Soc. 108 (1986) 1079-1080.

[29] J.P. Mahy, P. Battioni, G. Bedi, D. Mansuy, J. Fischer, R. Weiss, I. Morgenstern-Badarau, Inorg. Chem. 27 (1988) 353-359.

[30] J.P. Mahy, G. Bedi, P. Battioni, D. Mansuy, J. Chem. Soc., Perkin Trans. 2 (1988) 1517-1524.

[31] J.-P. Simonato, J. Pécaut, J.-C. Marchon, W. Robert Scheidt, Chem. Commun. (1999) 989-990.

[32] R. Vyas, G.-Y. Gao, J.D. Harden, X.P. Zhang, Org. Lett. 6 (2004) 1907-1910.

[33] Y. Liu, C.-M. Che, Chem.-Eur. J. 16 (2010) 10494-10501.

[34] C.C. Farwell, R.K. Zhang, J.A. McIntosh, T.K. Hyster, F.H. Arnold, ACS Cent. Sci. 1 (2015) 89-93.

[35] Y. Moreau, H. Chen, E. Derat, H. Hirao, C. Bolm, S. Shaik, J. Phys. Chem. B 111 (2007) 10288-10299.

[36] E.R. King, E.T. Hennessy, T.A. Betley, J. Am. Chem. Soc. 133 (2011) 4917-4923.

[37] E.T. Hennessy, R.Y. Liu, D.A. Iovan, R.A. Duncan, T.A. Betley, Chem. Sci. 5 (2014) 1526-1532.

[38] D.A. Iovan, T.A. Betley, J. Am. Chem. Soc. 138 (2016) 1983-1993.

[39] S.-M. Au, J.-S. Huang, W.-Y. Yu, W.-H. Fung, C.-M. Che, J. Am. Chem. Soc. 121 (1999) 9120-9132.

[40] J.-L. Liang, J.-S. Huang, X.-Q. Yu, N. Zhu, C.-M. Che, Chem. Eur. J. 8 (2002) 1563-1572.

[41] J.-L. Zhang, C.-M. Che, Org. Lett. 4 (2002) 1911-1914. 
[42] C.-M. Che, W.-Y. Yu, Pure Appl. Chem. 71 (1999) 281-288.

[43] J.-L. Liang, S.-X. Yuan, J.-S. Huang, C.-M. Che, J. Org. Chem. 69 (2004) 3610-3619.

[44] S. Fantauzzi, E. Gallo, A. Caselli, C. Piangiolino, F. Ragaini, S. Cenini, Eur. J. Org. Chem. (2007) 6053-6059.

[45] C. Piangiolino, E. Gallo, A. Caselli, S. Fantauzzi, F. Ragaini, S. Cenini, Eur. J. Org. Chem. (2007) 743750.

[46] S. Fantauzzi, E. Gallo, A. Caselli, C. Piangiolino, F. Ragaini, N. Re, S. Cenini, Chem. Eur. J 15 (2009) 1241-1251.

[47] E. Gallo, P. Zardi, A. Pozzoli, F. Ferretti, G. Manca, C. Mealli, Dalton Trans. 44, (2015) 10479-10489.

[48] S. Fantauzzi, E. Gallo, A. Caselli, F. Ragaini, P. Macchi, N. Casati, S. Cenini, Organometallics 24 (2005) 4710-4713.

[49] S. Soltani, M. Sahimi, T. Tsotsis, E.M.V. Hoek, V.V. Tarabara, Catalytic Membrane Reactors, Encyclopedia of Membrane Science and Technology, John Wiley \& Sons, Inc. 2013.

[50] M.G. Buonomenna, E. Gallo, F. Ragaini, A. Caselli, S. Cenini, E. Drioli, Appl. Catal., A 335 (2008) 3745.

[51] M.G. Buonomenna, E. Gallo, F. Ragaini, S. Cenini, E. Drioli, Desalination 199 (2006) 167-169.

[52] E. Gallo, M.G. Buonomenna, L. Vigano, F. Ragaini, A. Caselli, S. Fantauzzi, S. Cenini, E. Drioli, J. Mol. Catal. A: Chem. 282 (2008) 85-91.

[53] J.-L. Zhang, J.-S. Huang, C.-M. Che, Chem. Eur. J. 12 (2006) 3020-3031.

[54] M. Weber, G. Yilmaz, G. Wille, Chim. Oggi 29 (2011) 8-10.

[55] S. Rossi, A. Puglisi, M. Benaglia, D.M. Carminati, D. Intrieri, E. Gallo, Catal. Sci. Technol. 6 (2016) 4700-4704.

[56] S. Rossi, A. Puglisi, D. Intrieri, E. Gallo, J. Flow Chem. 6 (2016) 234-239.

[57] K.-H. Chan, X. Guan, V.K.-Y. Lo, C.-M. Che, Angew. Chem. Int. Ed. 53 (2014) 2982-2987.

[58] P. Zardi, D. Intrieri, D.M. Carminati, F. Ferretti, P. Macchi, E. Gallo, J. Porphyrins Phthalocyanines 20 (2016) 1156-1165.

[59] J.P. Collman, C.E. Barnes, P.J. Brothers, T.J. Collins, T. Ozawa, J.C. Gallucci, J.A. Ibers, J. Am. Chem. Soc. 106 (1984) 5151-5163.

[60] S.-M. Law, D. Chen, S.L.-F. Chan, X. Guan, W.-M. Tsui, J.-S. Huang, N. Zhu, C.-M. Che, Chem. Eur. J. 20 (2014) 11035-11047.

[61] Z. Guo, X. Guan, J.-S. Huang, W.-M. Tsui, Z. Lin, C.-M. Che, Chem. Eur. J. 19 (2013) 11320-11331.

[62] S.-Y. Yan, Y. Wang, Y.-J. Shu, H.-H. Liu, X.-G. Zhou, J. Mol. Catal. A: Chem. 248 (2006) 148-151.

[63] L. Liang, H. Lv, Y. Yu, P. Wang, J.-L. Zhang, Dalton Trans. 41 (2012) 1457-1460.

[64] Z. Li, K.R. Conser, E.N. Jacobsen, J. .Am. Chem. Soc. 115 (1993) 5326.

[65] K. Noda, N. Hosoya, R. Irie, Y. Ito, T. Katsuki, Synlett (1993) 469-471.

[66] H. Nishikori, T. Katsuki, Tetrahedron Lett. 37 (1996) 9245-9248.

[67] K.M. Gillespie, E.J. Crust, R.J. Deeth, P. Scott, Chem. Commun. (2001) 785-786.

[68] K.M. Gillespie, C.J. Sanders, P. O'Shaughnessy, I. Westmoreland, C.P. Thickitt, P. Scott, J. Org. Chem. 67 (2002) 3450-3458.

[69] K. Omura, M. Murakami, T. Uchida, R. Irie, T. Katsuki, Chem. Lett. 32 (2003) 354-355.

[70] K. Omura, T. Uchida, R. Irie, T. Katsuki, Chem. Commun. (2004) 2060-2061.

[71] H. Kawabata, K. Omura, T. Katsuki, Tetrahedron Lett. 47 (2006) 1571-1574.

[72] H. Kawabata, K. Omura, T. Uchida, T. Katsuki, Chem. Asian J. 2 (2007) 248-256.

[73] Y. Fukunaga, T. Uchida, Y. Ito, K. Matsumoto, T. Katsuki, Org. Lett. 14 (2012) 4658-4661.

[74] C. Kim, T. Uchida, T. Katsuki, Chem. Commun. 48 (2012) 7188-7190.

[75] S.A. Cramer, D.M. Jenkins, J. Am. Chem. Soc. 133 (2011) 19342-19345.

[76] D.M. Jenkins, Synlett 23 (2012) 1267-1270.

[77] S.A. Cramer, R. Hernandez Sanchez, D.F. Brakhage, D.M. Jenkins, Chem. Commun. 50 (2014) 1396713970.

[78] P.P. Chandrachud, H.M. Bass, D.M. Jenkins, Organometallics, 35 (2016) 1652-1657.

[79] S.B. Muñoz, W.-T. Lee, D.A. Dickie, J.J. Scepaniak, D. Subedi, M. Pink, M.D. Johnson, J.M. Smith, Angew. Chem. Int. Ed. 54 (2015) 10600-10603.

[80] K.L. Klotz, L.M. Slominski, A.V. Hull, V.M. Gottsacker, R. Mas-Ballesté, J.L. Que, J.A. Halfen, Chem. Commun. (2007) 2063-2065.

[81] M.R. Bukowski, H.L. Halfen, T.A. van den Berg, J.A. Halfen, L. Que, Angew. Chem. Int. Ed. 44 (2005) 584-587. 
[82] Y. Zang, J. Kim, Y. Dong, E.C. Wilkinson, E.H. Appelman, L. Que, J. Am. Chem. Soc. 119 (1997) 4197-4205.

[83] G. Roelfes, M. Lubben, K. Chen, R.Y.N. Ho, A. Meetsma, S. Genseberger, R.M. Hermant, R. Hage, S.K. Mandal, V.G. Young, Y. Zang, H. Kooijman, A.L. Spek, L. Que, B.L. Feringa, Inorg. Chem. 38 (1999) 1929-1936.

[84] K.L. Klotz, L.M. Slominski, M.E. Riemer, J.A. Phillips, J.A. Halfen, Inorg. Chem. 48 (2009) 801-803.

[85] M. Nakanishi, A.-F. Salit, C. Bolm, Adv. Synth. Catal. 350 (2008) 1835-1840.

[86] A.C. Mayer, A.-F. Salit, C. Bolm, Chem. Commun. (2008) 5975-5977.

[87] P. Liu, E.L.-M. Wong, A.W.-H. Yuen, C.-M. Che, Org. Lett. 10 (2008) 3275-3278.

[88] S. Liang, M.P. Jensen, Organometallics 31 (2012) 8055-8058. 